Check for updates

Cite this: RSC Adv., 2018, 8, 32401

Received 17th June 2018

Accepted 4th September 2018

DOI: $10.1039 / c 8 r a 05204 b$

rsc.li/rsc-advances

\section{Low molecular weight galactomannans-based standardized fenugreek seed extract ameliorates high-fat diet-induced obesity in mice via modulation of FASn, IL-6, leptin, and TRIP-Br2†}

\begin{abstract}
Amit D. Kandhare, (D) ${ }^{\star a}$ Debasish Bandyopadhyay ${ }^{\mathrm{b}}$ and Prasad A. Thakurdesai ${ }^{\mathrm{a}}$
Background: Obesity is a complex, chronic metabolic disorder and its prevalence is increasing throughout most of the world. Low molecular weight galactomannans-based standardized fenugreek seed extract (LMWGAL-TF) has previously shown anti-diabetic and anti-hyperlipidemic potential. Aim: To evaluate the efficacy and mechanism of action of LMWGAL-TF in treating high fat diet (HFD)-induced obesity and hyperlipidemia in mice. Materials and methods: Male C57BL/6 mice were fed the HFD for 12 weeks and were co-administered with LMWGAL-TF (10, 30 and $100 \mathrm{mg} \mathrm{kg}^{-1}$, p.o.). Variables measured were behavioral, biochemical, molecular and histopathological. In a separate in vitro experiment, copper-ascorbate (Cu-As)-induced mitochondrial oxidative damage was evaluated. Results: The HFD-induced increase $(p<0.001)$ in body weight, fat mass, lean mass, adipose tissue (brown, mesenteric, epididymal and retroperitoneal) and liver weight was significantly attenuated $(p<0.001)$ by LMWGAL-TF $\left(30\right.$ and $100 \mathrm{mg} \mathrm{kg}^{-1}$ ). The HFD-induced elevated levels of serum lipid, interleukins (ILs)- 6 and leptin were significantly decreased $(p<0.001)$ by LMWGAL-TF (30 and $100 \mathrm{mg} \mathrm{kg}^{-1}$ ). Elevated fatty acid synthase (FASn), IL-6, leptin and transcriptional regulator interacting with the PHD-bromodomain 2 (TRIP-Br2) mRNA expression in brown adipose tissue (BAT), liver, and epididymal fat were significantly down-regulated $(p<0.001)$ by LMWGAL-TF $\left(30\right.$ and $100 \mathrm{mg} \mathrm{kg}^{-1}$ ). Additionally, HFDinduced histological alterations in skeletal muscle, liver, white adipose tissue (WAT) and BAT were also reduced by LMWGAL-TF. Furthermore, the Cu-As-induced alteration in mitochondria oxidative stress (lipid peroxidation, protein carbonylation, glutathione, glutathione reductase, glutathione peroxidase, isocitrate dehydrogenase and $\alpha$-ketoglutarate dehydrogenase) in skeletal muscle and BAT was significantly $(p<0.001)$ ameliorated by LMWGAL-TF (2, 4 and $6 \mathrm{mg} \mathrm{mL}^{-1}$ ) treatment. It also reduced the Cu-As-induced mitochondrial swelling. Conclusion: LMWGAL-TF showed its beneficial effect in reducing HFD-induced obesity via down-regulation of FASn, IL-6, leptin, and TRIP-Br2 in mice.
\end{abstract}

\section{Introduction}

Type 2 diabetes mellitus (T2DM) is a complex, chronic metabolic disorder across the world. An array of conditions such as imbalanced eating habits, high-fat diet (HFD), excessive caloric intake, reduced physical activity, sedentary lifestyles and neuroendocrine factors integrated with T2DM leads to increased obesity, which is now becoming one of the most severe threats. ${ }^{1}$ Obesity in the population has increased significantly over the past decades and has now become a major factor responsible for morbidity and

${ }^{a}$ Department of Scientific Affairs, Indus Biotech Private Limited, 1, Rahul Residency, Off Salunke Vihar Road, Kondhwa, Pune 411048, Maharashtra, India. E-mail: amit. kandhare@indusbiotech.com; Tel: +91-9226164041

${ }^{b}$ Oxidative Stress and Free Radical Biology Laboratory, Department of Physiology, University of Calcutta, University College of Science and Technology, Kolkata 700 009, India

$\dagger$ Electronic supplementary information (ESI) available. See DOI: 10.1039/c8ra05204b mortality worldwide. ${ }^{2}$ In 2016, there were more than 1.9 billion adults that were overweight, and of these, over 650 million were obese, whereas 41 million children were overweight or obese. ${ }^{3}$ It has been reported that obesity is also associated with other diseases such as cardiovascular disease, dyslipidemia, cerebrovascular disease, hypertension, non-alcoholic fatty liver disease and arthritis, which diminish the quality of life. ${ }^{4}$

Several mechanisms have been proposed to explain T2DMinduced obesity. Researchers have established the correlation between oxido-inflammatory stress and the development of metabolic disorders associated with obesity. ${ }^{5,6}$ White adipose tissue (WAT) plays a vital role in this oxido-inflammatory-induced obesity and dyslipidemia. Adipose tissue is well known for releasing and controlling adipokines (leptin and adiponectin) and cytokines (tumor necrosis factor- $\alpha$ (TNF- $\alpha$ ) and interleukin- 6 (IL-6)). ${ }^{7}$ It has been well documented that increased oxidative stress in adipocytes causes an imbalance between the leptin and adiponectin, leading to profound metabolic alterations that 
result in obesity-related comorbidities. ${ }^{\mathbf{8} 9}$ Furthermore, adipose tissue serves as energy storage and accumulates triglycerides during excess nutritional intake and releases free fatty acids (FFA) when there is the need for energy. Lipogenesis and lipolysis are controlled by various enzymes such as fatty acid synthase (FAS), and impaired levels of FAS lead to an imbalance in lipid metabolism that results in increased adipose tissue mass ${ }^{\mathbf{1 0}}$ and consequently results in obesity and related disorders. ${ }^{11}$

Obesity has a great impact on the quality of life as well as socioeconomic status. ${ }^{\mathbf{1 2}}$ Much evidence has demonstrated that a HFD rich in saturated fatty acids results in an elevated inflammatory response, increased serum leptin levels and increased mass of adipose cells. ${ }^{\mathbf{1 3 - 1 5}}$ Therefore, various dietary recommendations have been implemented to reduce systemic inflammation, which decreases the risk for conditions associated with obesity including cardiovascular disease and other metabolic disorders. ${ }^{16}$ Additionally, lifestyle changes such as weight reduction, exercise, and diet control have also been recommended as a first-line intervention to decrease obesity. These have advantages such as ease of access and lower cost of surgery or pharmacotherapy. However, they are difficult to maintain over a longer period. ${ }^{\mathbf{1 7}}$

The current treatment regimen for obesity includes sibutramine, rimonabant, lorcaserin, and orlistat, ${ }^{18}$ however, these pharmaceuticals have potential side effects and also induce economic burden. ${ }^{19}$ Hence, there is a need to develop treatment options for obesity, which should be more effective as well as safe. In recent years, health remedies from medicinal plants have been highlighted for their maximal preventive outcome and the least side effects for the treatment of various maladies. ${ }^{20}$ A number of experimental and clinical trials have indicated the potential effectiveness of natural remedies against the management of obesity. $^{21-27}$

An animal model is a useful tool in the development of various potential moieties for the management of obesity. Among the various animal models of dyslipidemia and obesity, HFD-induced obesity is one such model that is gaining importance nowadays. HFD-induced obesity in C57BL/6 mice is a robust, well established and reproducible animal model that mimics all the clinicopathological features of HFD-induced obesity in humans. ${ }^{28-30}$ Mice administered with HFD showed important features like increased weight gain and elevated plasma FFAs, which lead to the development of obesity, hyperleptinemia, and hypertriglyceridemia. ${ }^{31}$ Previous studies revealed that a HFD leads to the progressive accumulation of lipid, activation of proinflammatory cytokines (such as TNF- $\alpha$ and IL-6) and the elevation of oxidative stress, which play an important role in the development of metabolic syndromes such as obesity and hyperlipidemia. ${ }^{31}$

Fenugreek (Trigonella foenum-graecum L.) is a leguminous plant native to many Asian, Middle Eastern, European countries, and India. In Ayurveda, fenugreek seeds are used for their therapeutic action against a wide range of disease states including diabetes, inflammation, bronchitis, pneumonia, fever, hypertension, etc. The pharmacological evidence has demonstrated that fenugreek possesses antiviral, antimicrobial, antioxidant, antidiabetic, anti-inflammatory, antihypertensive, antihyperlipidemic, and antitumor activities. ${ }^{32-36}$ The fenugreek seed contains a variety of chemical constituents that include alkaloids (such as trigonelline, gentianine, carpaine, etc.), furastanols (like vicenin-1, vitexin, diosgenin, gitogenin, yamogenin), free amino acids (4-hydroxyisoleucine), protein, mucilaginous soluble fiber and insoluble fiber, fixed fatty acids, essential oils, steroidal saponins, etc. $^{37,38}$

Galactomannans (GAL) present in fenugreek seeds are about $50 \%$ of the total seed weight $t^{39}$ and have been shown to exert health benefits in preclinical and clinical settings. ${ }^{40}$ Researchers have reported their antidiabetic, anabolic and androgenic activity in rats. $^{\text {41,42 }}$ GAL-based standardized fenugreek seed extract (LMWGAL-TF) exhibits protective efficacy against HFD-induced insulin resistance in mice. ${ }^{43}$ Notably, GAL has been demonstrated to decrease blood glucose, increase insulin sensitivity as well as decrease total cholesterol and low-density lipoprotein (LDL) cholesterol levels in both diabetic and healthy subjects. ${ }^{44-48}$ Clinically, the supplementation of LMWGAL-TF during resistancetraining was shown to improve body composition in resistance trained men. ${ }^{49}$ Thus, GAL isolated from fenugreek seed could be important candidates for the treatment of obesity and related metabolic syndromes. Although LMWGAL-TF has shown its potential in the reduction of body fat in resistance trained men, its mechanism of action in obesity and its related metabolic syndromes remain unknown. Hence, the objective of the present investigation is to evaluate the efficacy and mechanism of action of LMWGAL-TF in an animal model of HFD-induced obesity and hyperlipidemia.

\section{Materials and methods}

\subsection{Animals}

Male C57BL/6 mice (age 4 weeks) were used in the study and they were housed in cages at a temperature of $19.1-23.6^{\circ} \mathrm{C}$, and relative humidity 56-66\%, with $12 \mathrm{~h}$ fluorescent light and $12 \mathrm{~h}$ dark cycles in an accredited animal facility (Bioneeds, Bangalore, India, and Edara Research Foundation, Hyderabad, India). The mice had free access to water ad libitum throughout the study, except during actual measurements. All experiments were carried out between 09:00 $\mathrm{h}$ and 17:00 h. The Institutional Animal Ethics Committees (IAEC) of Bioneed (Bangalore, India) and Edara Research Foundation (Hyderabad, India) approved the experimental protocol (BIO-IAEC-477 and ERF/IAEC/O1OA, respectively). The experiments were performed in accordance with the guidelines on animal experimentation recommended by the Committee for Control and Supervision of Experimentation on Animals (CPCSEA), Government of India.

\subsection{Research diets}

The low-fat diet (LFD, 10\% kcal fat, \#D12450B, $3.85 \mathrm{kcal} \mathrm{g}^{-1}$ ) and HFD (60\% kcal fat, \#D12492, $5.24 \mathrm{kcal} \mathrm{g}^{-1}$ ) were purchased from Research Diet Inc., New Brunswick, NJ, USA.

\subsection{The test compound}

The test compound, LMWGAL-TF, was provided by Indus Biotech Private Limited (Pune, India) after preparation and characterization (HPLC and LC-MS) as per the reported 
procedure. ${ }^{41}$ Since LMWGAL-TF is water-soluble, the solution was freshly prepared daily as $1 \% \mathrm{w} / \mathrm{v}$ in distilled water and orally administered twice a day to mice in a volume of $10 \mathrm{mg} \mathrm{kg}^{-1}$. The vehicle or LMWGAL-TF was orally administered twice daily with approximately $8 \mathrm{~h}$ between the morning and evening administration using the intragastric tube for 12 weeks.

\subsection{Development of HFD induced obesity}

Mice were randomly divided into five groups $(n=12)$ and administered with treatments as well as diets as follows:

Group I: LFD control: received vehicle $\left(10 \mathrm{mg} \mathrm{kg}^{-1}\right.$ of distilled water, twice daily) + LFD

Group II: HFD control: received vehicle $\left(10 \mathrm{mg} \mathrm{kg}^{-1}\right.$ of distilled water, twice daily) + HFD

Group III: LMWGAL-TF (30): received LMWGAL-TF (30 mg $\mathrm{kg}^{-1}$ of LMWGAL-TF, twice daily) + HFD

Group IV: LMWGAL-TF (60): received LMWGAL-TF (60 mg $\mathrm{kg}^{-1}$ of LMWGAL-TF, twice daily) + HFD

Group V: LMWGAL-TF (100): received LMWGAL-TF (100 mg $\mathrm{kg}^{-1}$ of LMWGAL-TF, twice daily) + HFD.

The mice were caged individually, and the respective diet was supplied during the entire study period of 12 weeks. The doses of LMWGAL-TF (30, 60 and $100 \mathrm{mg} \mathrm{kg}^{-1}$, twice a day, oral) were derived from an $\mathrm{LD}_{50}$ dose of $2000 \mathrm{mg} \mathrm{kg}^{-1}$ found during the acute oral toxicity (AOT) study. ${ }^{50}$

\subsection{Body weight}

The body weights of the mice were recorded individually before grouping and three times a week thereafter, during the treatment period.

\subsection{Body composition analysis (Echo MRI)}

At week 12 , mice were selected ( $n=4$ /group) randomly from each group and body composition analysis was performed using MRI (Echo MRI, Whole Body Composition Analyzer) at the Centre for Cellular and Molecular Biology (CCMB), Hyderabad. Mice were individually scanned and the exact amounts of body fat deposits and lean mass were analyzed.

\subsection{Serum biochemistry}

At the end of the treatment period (terminal scarification), blood was collected from the mice ( $n=6$ /group) under mild isoflurane anesthesia. Serum was separated and was used to analyze total, high-density lipoprotein (HDL) and LDL cholesterol, triglycerides levels. The analysis was performed using the EM-200 clinical chemistry analyzer (Transasia Bio-Medicals Ltd., India).

\subsection{Determination of TNF- $\alpha$, IL-6, leptin and ghrelin levels}

The quantifications of TNF- $\alpha$, IL- 6 , leptin, and ghrelin were performed by using commercially available mice immunoassay kits (Ray Biotech Inc., USA).

\subsection{Gene expression analysis by RT-PCR}

Four tissue samples of brown adipose tissue (BAT), liver, and epididymal fat from each group were used for RT-PCR analysis using commercially available kits (Biotools B \& M Labs, Spain) according to the manufacturer's instructions. Total RNA was extracted from each tissue. The PCR mixture was amplified in a DNA thermal cycler (Eppendorf India Ltd, Chennai, India) by using gene-specific primers (ESI file $1 \dagger$ ). PCR products were run on $1 \%$ agarose gels, stained with ethidium bromide. The expression of all the genes was assessed by generating densitometry data for band intensities in different sets of experiments and was generated by analyzing the gel images on the Image J program (Version 1.33, Wayne Rasband, National Institutes of Health Bethesda, MD, USA). The band intensities were compared with constitutively expressed $\beta$-actin, which served as a control for sample loading and integrity. The intensity of mRNAs was standardized against that of the $\beta$-actin mRNA from each sample, and the results were expressed quantitatively as the PCR-product/ $\beta$-actin mRNA ratio.

\subsection{Histopathology}

The samples from skeletal muscle, white adipose tissue and brown adipose tissue were embedded in paraffin wax, sectioned at $4 \mu \mathrm{m}$ and stained with haematoxylin and eosin (H\&E) and observed under compound microscope using a Zeiss intravital microscopy setup (Zeiss Axioscope A1, Carl Zeiss MicroImaging, Jena, Germany) with a $40 \times$ magnification for histological examinations.

To assess hepatic lipid accumulation, liver samples were snap frozen using liquid nitrogen and cryosections were prepared for Oil-Red-O (ORO) staining. Histopathological analysis was performed by an independent pathologist, who was blinded to the treatment groups. Tissue sections were graded for congestion, hemorrhage, degeneration, inflammation, and steatosis according to a previously reported scoring system ( 0 : none; 1 : $<2 ; 2: 2-4$ and $3:>4) .51,52$

\subsection{Determination of copper-ascorbate ( $\mathrm{Cu}$-As)-induced mitochondrial oxidative damage}

The mitochondria from goat tissues such as skeletal muscle and brown adipose tissue were isolated according to the previously reported method with some modifications..$^{53,54}$ The mixture of mitochondrial membrane protein $\left(1.6 \mathrm{mg} \mathrm{mL}^{-1}\right)$ along with $0.2 \mathrm{mM} \mathrm{Cu}^{2+}$ and $1 \mathrm{mM}$ ascorbic acid and $50 \mathrm{mM}$ potassium phosphate buffer ( $\mathrm{pH} 7.4$ ), in a final volume of $1.0 \mathrm{~mL}$ was incubated at $37^{\circ} \mathrm{C}$ for $1 \mathrm{~h}$. The reaction was terminated with 40 $\mu \mathrm{L}$ of $35 \mathrm{mM}$ ethylenediaminetetraacetic acid (EDTA). ${ }^{55}$

In separate assays, the mitochondria of different goat tissues were co-incubated with copper-ascorbate and four different concentrations of LMWGAL-TF $\left(1,2,4\right.$ and $\left.6 \mathrm{mg} \mathrm{mL}^{-1}\right)$. After $1 \mathrm{~h}$ of the incubation period, the reaction was terminated, and levels of various enzymes were determined. The mitochondrial level of lipid peroxidation (LPO) was established in terms of thiobarbituric acid reactive substances (TBARS) using a previously reported method. ${ }^{56}$ The protein carbonylation (PCO) level was determined according to the previously reported method. ${ }^{57}$ The glutathione (GSH) content was measured by the reaction with DTNB (5,5'-dithiobis(2-nitrobenzoic acid), i.e., Ellman's reagent) according to the previously reported method ${ }^{58}$ with some modifications. ${ }^{54}$ The glutathione peroxidase (GPx) activity was determined according to 
the previously reported method ${ }^{59}$ with some modifications. ${ }^{60}$ The glutathione reductase (GR) activity was measured according to the previously reported method. ${ }^{61}$ Isocitrate dehydrogenase (ICDH) activity was determined according to the previously reported method. ${ }^{62}$ Alpha-ketoglutarate dehydrogenase ( $\alpha$-KGDH) activity was determined according to the previously reported method. ${ }^{62}$

\subsection{Measurement of mitochondrial swelling}

Mitochondrial swelling was measured by using spectrophotometry according to the previously reported method by determining the changes in absorbance at $520 \mathrm{~nm} .{ }^{63}$ Mitochondrial morphology was evaluated by scanning electron microscopy (SEM; Zeiss Evo 18 model EDS 8100). ${ }^{64}$

\subsection{Statistical analysis}

All statistical analysis was performed using GraphPad Prism 7.0 (GraphPad Software, Inc, La Jolla, CA, USA). Data were analyzed by separate one-way ANOVA followed by Dunnett's test separately for each parameter. A value of $p<0.05$ was considered statistically significant.

\section{Results}

3.1 The effects of LMWGAL-TF on HFD-induced alteration in body weight, fat mass and lean mass of mice

Body weights of HFD control mice were significantly increased as compared to the LFD control mice. Mice co-administered with LMWGAL-TF (10, 30 and $100 \mathrm{mg} \mathrm{kg}{ }^{-1}$, p.o.) were significantly protected from body weight gain $(p<0.001)$ as compared to the HFD control mice (Table 1).

Changes in body composition were analyzed using EchoMRI and the results revealed that there was a significant increase $(p<$ 0.001 and $p<0.05$ ) in fat mass and lean mass, respectively, in HFD control mice, as compared to LFD control mice. Mice coadministered with LMWGAL-TF (10, 30 and $100 \mathrm{mg} \mathrm{kg}^{-1}$, p.o.) had significantly reduced ( $p<0.001, p<0.05$ and $p<0.01$, resp.) fat mass as compared to the HFD control mice. There was a significant decrease $(p<0.01, p<0.01$ and $p<0.05)$ in the lean mass of LMWGAL-TF (10, 30 and $100 \mathrm{mg} \mathrm{kg}^{-1}$, p.o.) coadministered mice as compared to the HFD control mice (Table 1).

\subsection{The effects of LMWGAL-TF on the HFD-induced alterations in various organ weights of mice}

The weights of different adipose tissues (brown, mesenteric, epididymal and retroperitoneal) and total white adipose tissue were significantly increased $(p<0.001)$ in HFD control mice as compared to LFD control mice. There was a significant decrease $(p<0.001)$ in the weight of brown, mesenteric and retroperitoneal adipose tissue as well as total white adipose tissue in mice coadministered with LMWGAL-TF (10, 30 and $100 \mathrm{mg} \mathrm{kg}^{-1}$, p.o.) as compared to the HFD control mice. Mice co-administered with LMWGAL-TF (100 mg kg ${ }^{-1}$, p.o.) showed a significant decrease ( $p$ $<0.001$ ) in the weight of epididymal adipose tissue when compared with the HFD control mice (Table 1).

The liver weight of HFD control mice was significantly increased $(p<0.001)$ as compared to LFD control mice. The liver weight was significantly reduced $(p<0.001)$ in mice that were co-administered with LMWGAL-TF (10, 30 and $100 \mathrm{mg} \mathrm{kg}^{-1}$, p.o.) as compared to the HFD control mice. The weights of muscles (gastrocnemius and soleus) did not differ significantly among any groups (Table 1).

\subsection{The effects of LMWGAL-TF on the HFD-induced alteration in food intake, water intake and calorie intake of mice}

There was no significant change in feed intake and water intake in the HFD control mice as compared to the LFD control mice. Moreover, mice co-administered with LMWGAL-TF (10, 30 and $100 \mathrm{mg} \mathrm{kg}^{-1}$, p.o.) also did not show any significant change in feed intake and water intake as compared to the HFD control

Table 1 The effects of LMWGAL-TF on HFD-induced alteration in body weight, fat mass, lean mass and organ weights in mice ${ }^{a}$

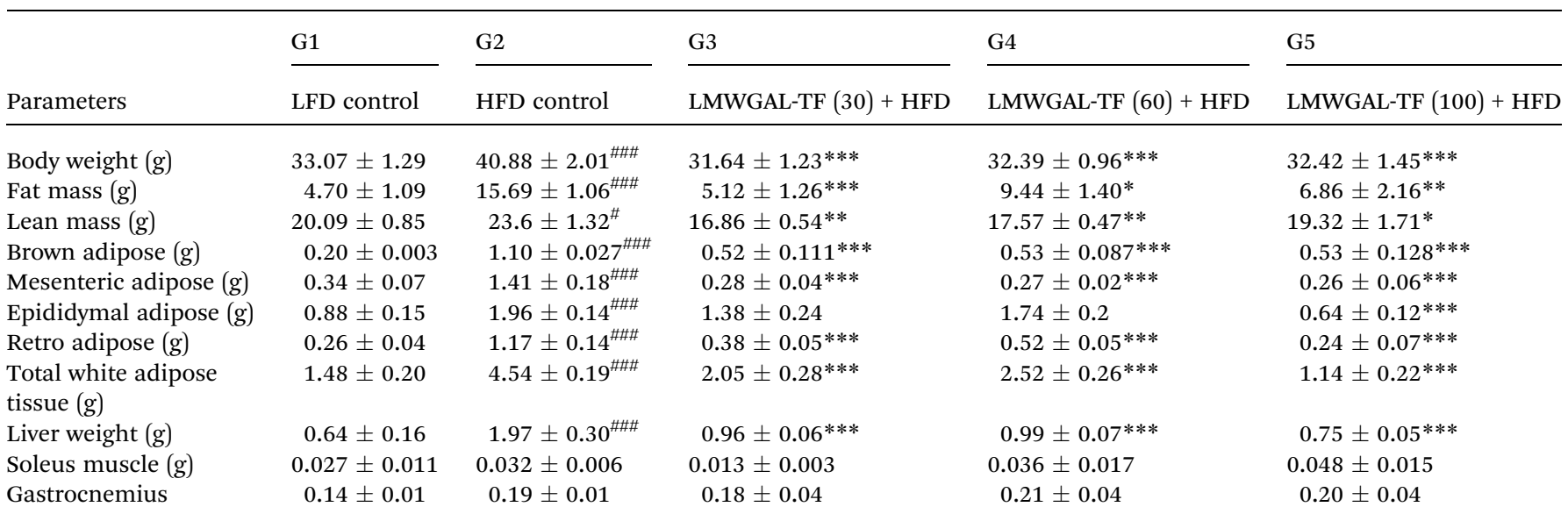

muscle $(\mathrm{g})$

\footnotetext{
${ }^{a}$ Data are expressed as mean \pm S.E.M. ( $n=12$ for body weight, $n=4-6$ for remaining parameters) and analyzed by one-way ANOVA followed by Dunnett's test for each parameter separately. ${ }^{*} p<0.05,{ }^{* *} p<0.01,{ }^{* * *} p<0.001$ as compared to HFD group and ${ }^{\#} p<0.05$, \#\#\# $p<0.001$ as compared to LFD group. LFD: Low Fat Diet; LMWGAL-TF: low molecular eeight galactomannans-based standardized fenugreek seeds extract; HFD: High Fat Diet. Figure in parenthesis for LMWGAL-TF indicates the dose in $\mathrm{mg} \mathrm{kg}^{-1}$.
} 


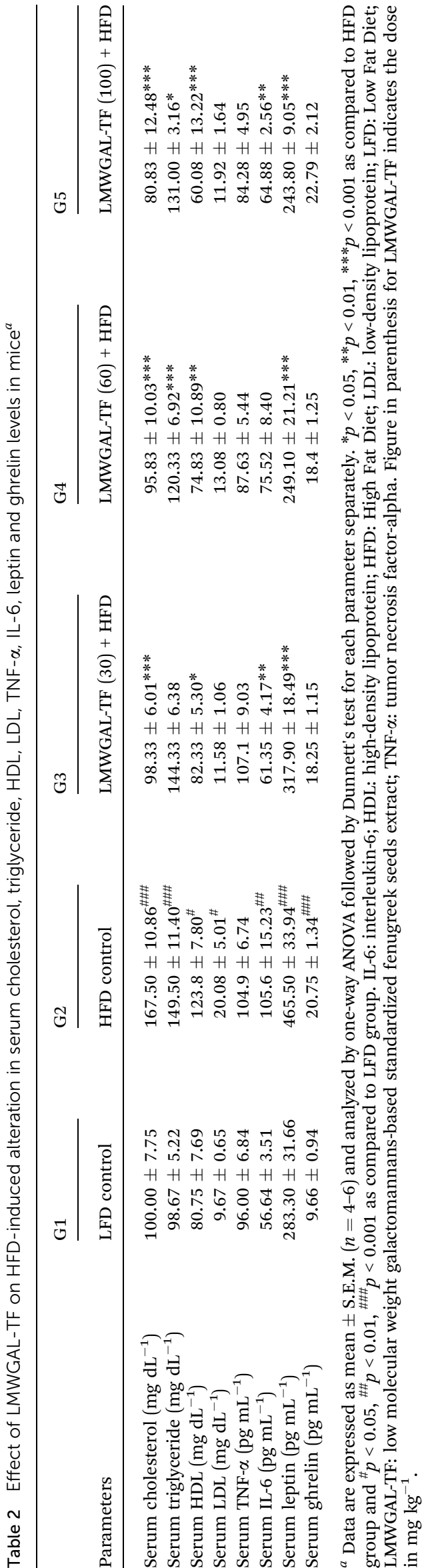

mice. However, when compared with the LFD control mice, the calorie intake in the HFD control mice was significantly increased $(p<0.05)$ as compared to the LFD control mice. There were no significant difference in the calorie intake in LMWGALTF $\left(10,30\right.$ and $100 \mathrm{mg} \mathrm{kg}^{-1}$, p.o.) co-administered mice as compared to HFD control mice (ESI file $2 \dagger$ ).

\subsection{The effects of LMWGAL-TF on the HFD-induced alteration in the serum cholesterol, triglyceride, HDL, and LDL levels of mice}

At week 12, the analysis of the serum lipid profile demonstrated significantly increased $(p<0.001)$ levels of total cholesterol and triglycerides in HFD control mice as compared to LFD control mice. The co-administration of LMWGAL-TF $(10,30$ and $100 \mathrm{mg}$ $\mathrm{kg}^{-1}$, p.o.) provided significant protection $(p<0.001)$ from an increased level of cholesterol as compared to HFD control mice. Mice co-administered with LMWGAL-TF (30 and $100 \mathrm{mg} \mathrm{kg}^{-1}$, p.o.) showed a significant reduction $(p<0.001$ and $p<0.05)$ in the serum triglyceride levels as compared to the HFD control mice (Table 2).

The HDL cholesterol and LDL cholesterol levels were significantly increased $(p<0.05)$ in the HFD control mice as compared to the LFD control mice. Mice co-administered with

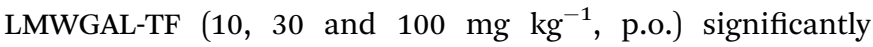
reduced ( $p<0.05, p<0.01$ and $p<0.001$, resp.) the level of HDL cholesterol in a dose-dependent manner as compared to the LFD control mice. However, there was no significant change in the LDL cholesterol level in mice co-administered with LMWGAL-TF (10, 30 and $100 \mathrm{mg} \mathrm{kg}^{-1}$, p.o.) as compared to the HFD vehicle control mice (Table 2).

\subsection{The effects of LMWGAL-TF on the HFD-induced alteration in serum TNF- $\alpha$ and IL-6 levels of mice}

There was a significant increase $(p<0.01)$ in the serum IL-6 levels in the HFD control mice as compared to the LFD control mice. The co-administration of LMWGAL-TF (30 and $100 \mathrm{mg} \mathrm{kg}^{-1}$, p.o.) significantly decreased $(p<0.01)$ the level of serum IL-6 as compared to the HFD control mice; however, the LMWGAL-TF (60 $\mathrm{mg} \mathrm{kg} \mathrm{kg}^{-1}$, p.o.) co-administration failed to reduce the elevated serum IL-6 as compared to the HFD control mice. Moreover, the serum TNF- $\alpha$ levels did not differ significantly in the HFD control mice when compared with the LFD control mice as well as the LMWGAL-TF co-administered group (Table 2).

\subsection{The effects of LMWGAL-TF on the HFD-induced alteration in serum leptin and ghrelin levels of mice}

Serum leptin levels were significantly increased $(p<0.001)$ in the HFD control mice as compared to the LFD control mice. The coadministration of LMWGAL-TF (10, 30 and $100 \mathrm{mg} \mathrm{kg}^{-1}$, p.o.) significantly ameliorated $(p<0.001)$ the HFD-induced increase in serum leptin levels as compared to the HFD-control mice. There was a significant increase $(p<0.001)$ in the level of serum ghrelin in the HFD control mice as compared to the LFD control mice. However, the co-administration of LMWGAL-TF did not produce any significant alterations in the elevated level of serum ghrelin as compared to the HFD control mice (Table 2). 
3.7 The effects of LMWGAL-TF on the HFD-induced alteration in the mRNA expression of FASn, IL-6, leptin, and TRIP-Br2 in the BAT of mice

The levels of FASn, IL-6, leptin and TRIP-Br2 mRNA expression in the BAT tissue of the HFD control mice was significantly upregulated $(p<0.001)$ as compared to the LFD control mice. The co-administration of LMWGAL-TF $\left(30,60\right.$ and $100 \mathrm{mg} \mathrm{kg}^{-1}$, p.o.) significantly down-regulated ( $p<0.01, p<0.001$ and $p<$ 0.001 , resp.) FASn mRNA expression in BAT tissue as compared to the HFD control mice. Co-administration of LMWGAL-TF (60 and $100 \mathrm{mg} \mathrm{kg}{ }^{-1}$, p.o.) significantly and dose-dependently attenuated $(p<0.01$ and $p<0.001$, resp.) the up-regulated mRNA expression of IL-6 and TRIP-Br2 in BAT tissue as compared to the HFD control mice. Up-regulated leptin mRNA expression in BAT tissue was significantly down-regulated $(p<$ 0.001 ) by the LMWGAL-TF (60 and $100 \mathrm{mg} \mathrm{kg}^{-1}$, p.o.) coadministration when compared with HFD control mice (Fig. 1).

3.8 The effects of LMWGAL-TF on the HFD-induced alteration in mRNA expression of FASn and IL-6 in the liver of mice

The FASn and IL-6 mRNA expression in the liver of the HFD control mice was significantly up-regulated $(p<0.001)$ as compared to the LFD control mice. This up-regulated liver IL-6 mRNA expression was significantly and dose-dependently attenuated ( $p<0.01$ and $p<0.001$, resp.) by the co-administration of
LMWGAL-TF (60 and $100 \mathrm{mg} \mathrm{kg}^{-1}$, p.o.) as compared to the HFD control mice. When compared with the HFD control mice, the liver FASn mRNA expression was significantly down-regulated ( $p$ $<0.01, p<0.001$ and $p<0.001)$ by LMWGAL-TF $(30,60$ and $100 \mathrm{mg} \mathrm{kg}^{-1}$, p.o.) co-administration (Fig. 2A-C).

\subsection{The effects of LMWGAL-TF on the HFD-induced} alteration in mRNA expression of leptin and TRIP-Br2 in the epididymal fat of mice

There was a significant up-regulation $(p<0.001)$ in the epididymal mRNA expression of leptin in the HFD control mice when compared with the LFD control mice. Co-administration of LMWGAL-TF (60 and $100 \mathrm{mg} \mathrm{kg}^{-1}$, p.o.) significantly and dosedependently ( $p<0.05$ and $p<0.001$ ) down-regulated this leptin mRNA expression in the epididymis as compared to the HFD control mice. However, the epididymal TRIP-Br2 mRNA expression of HFD control mice did not differ significantly as compared to the LFD control mice. The LMWGAL-TF (30, 60 and $100 \mathrm{mg}$ $\mathrm{kg}^{-1}$, p.o.) co-administered group also did not produce any significant change in the epididymal TRIP-Br2 mRNA expression as compared to the HFD control mice (Fig. 2A, D and 2E).

\subsection{The effects of LMWGAL-TF on the HFD-induced} histological alterations in the skeletal muscle, white adipose tissue and brown adipose tissue of mice

Histopathologic examination of skeletal muscle (Fig. 3A), white adipose tissue (Fig. 3F) and brown adipose tissue (Fig. 3K) of
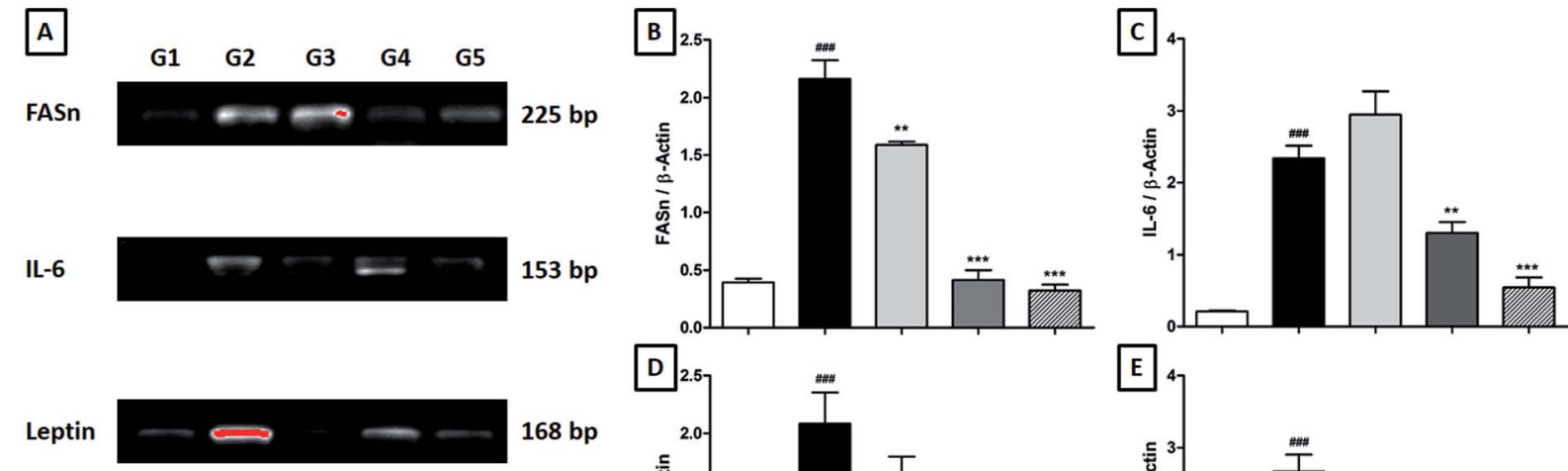

$168 \mathrm{bp}$

TRIP-Br2

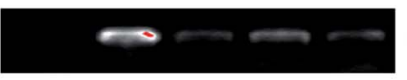

201 bp

$\beta$-actin

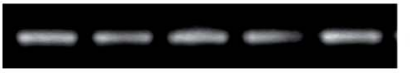

255 bp
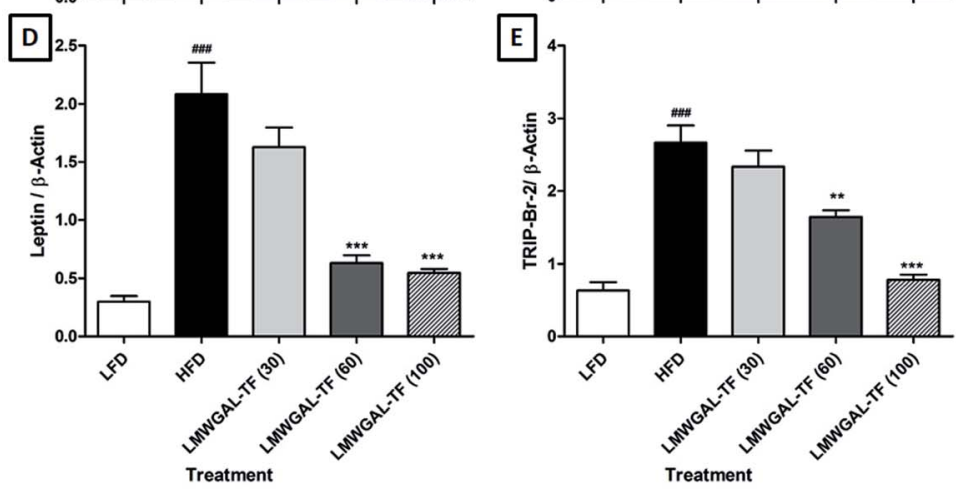

Fig. 1 The effects of LMWGAL-TF on the HFD-induced alteration in reverse transcriptase analysis of mRNA expression of FASn, IL-6, leptin and TRIP-Br2 in brown adipose tissue (A). A quantitative representation of mRNA expression of FASn (B), IL-6 (C), leptin (D) and TRIP-Br2 (E). Data are expressed as mean \pm S.E.M. $(n=4)$ and analyzed by one-way ANOVA followed by Dunnett's test for each parameter separately. ** $p<0.01$, *** $p<$

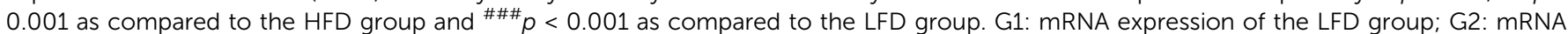
expression of the HFD control group; G3: mRNA expression of the LMWGAL-TF (30 $\mathrm{mg} \mathrm{kg}^{-1}$ ) treated + HFD group; G4: mRNA expression of the LMWGAL-TF $\left(60 \mathrm{mg} \mathrm{kg}^{-1}\right)$ treated + HFD group; G5: mRNA expression of the LMWGAL-TF $\left(100 \mathrm{mg} \mathrm{kg}^{-1}\right)$ treated + HFD group. FASn: fatty acid synthase; HFD: High Fat Diet; IL-6: interleukin-6; LFD: Low Fat Diet; LMWGAL-TF: low molecular weight galactomannans-based standardized fenugreek seeds extract; TRIP-Br2: transcriptional regulator interacting with the PHD-bromodomain 2. Figure in parenthesis for LMWGAL-TF indicates the dose in $\mathrm{mg} \mathrm{kg}^{-1}$. 


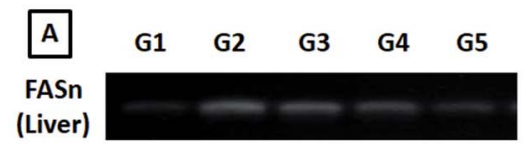

225 bp

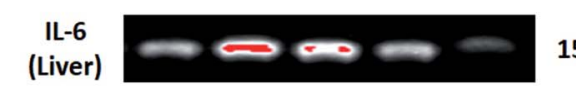

$153 \mathrm{bp}$

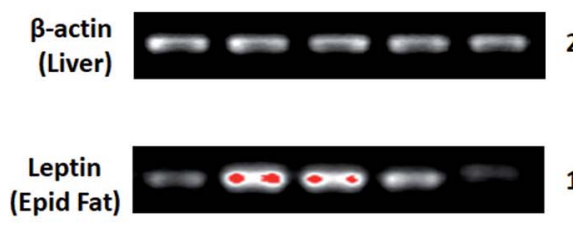

255 bp

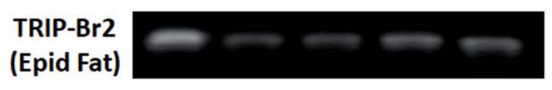

201 bp

\section{$\beta$-actin} (Epid Fat)

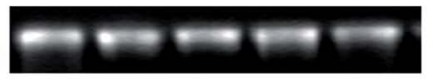

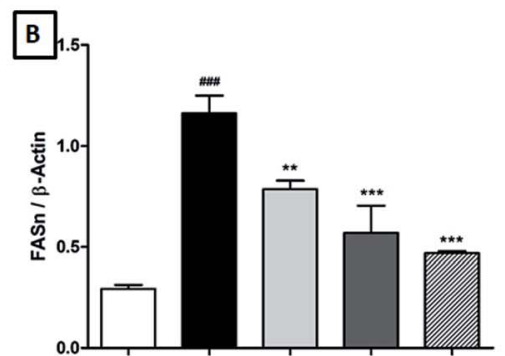

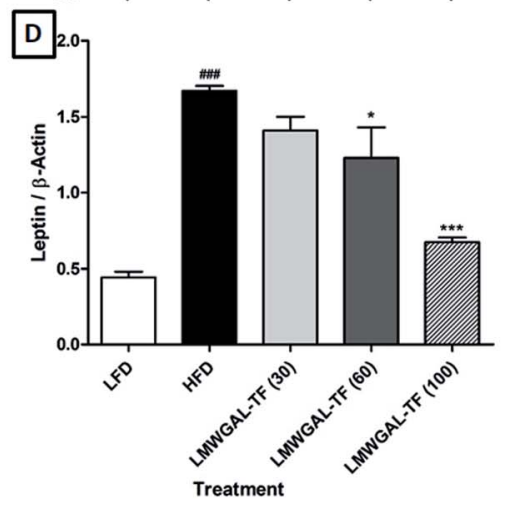

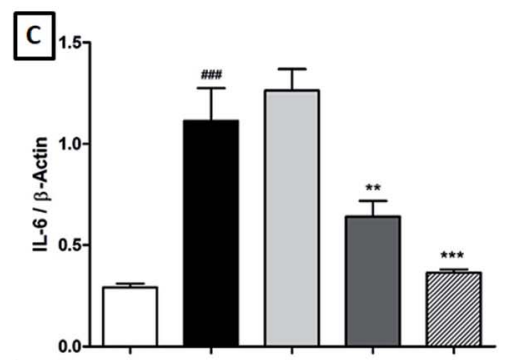

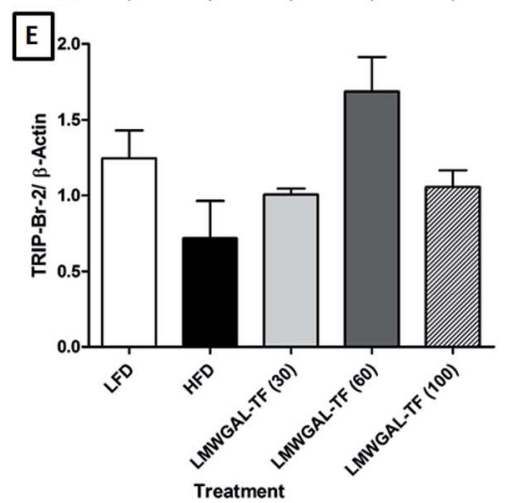

Fig. 2 The effects of LMWGAL-TF on HFD-induced alteration in the reverse transcriptase analysis of mRNA expression of FASn and IL- 6 in liver, leptin and TRIP-Br2 in epididymal fat (A). Quantitative representation of mRNA expression of FASn (B) and IL-6 (C) in the liver, leptin (D) and TRIP$\mathrm{Br} 2(\mathrm{E})$ in epididymal fat. Data are expressed as mean \pm S.E.M. $(n=4)$ and analyzed by one-way ANOVA followed by Dunnett's test for each

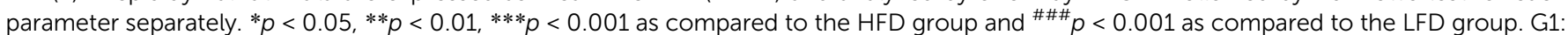
mRNA expression of the LFD group; G2: mRNA expression of the HFD control group; G3: mRNA expression of the LMWGAL-TF (30 mg kg ${ }^{-1}$ ) treated + HFD group; G4: mRNA expression of the LMWGAL-TF $\left(60 \mathrm{mg} \mathrm{kg}^{-1}\right)$ treated + HFD group; G5: mRNA expression of the LMWGAL-TF $\left(100 \mathrm{mg} \mathrm{kg}^{-1}\right)$ treated + HFD group. FASn: fatty acid synthase; HFD: High Fat Diet; IL-6: interleukin-6; LFD: Low Fat Diet; LMWGAL-TF: low molecular weight galactomannans-based standardized fenugreek seed extract; TRIP-Br2: transcriptional regulator interacting with the PHDbromodomain 2. Figure in parenthesis for LMWGAL-TF indicates the dose in $\mathrm{mg} \mathrm{kg}^{-1}$.

mice fed with LFD showed normal structure and architecture. Chronic HFD administration induced mild congestion, hemorrhage, and mild inflammation in skeletal muscle (Fig. 3B), and brown adipose tissue (Fig. 3L). However, these pathological damages induced by HFD were ameliorated by LMWGAL-TF (60 and $100 \mathrm{mg} \mathrm{kg}^{-1}$, p.o.) co-administration (Table 3 and Fig. 3).
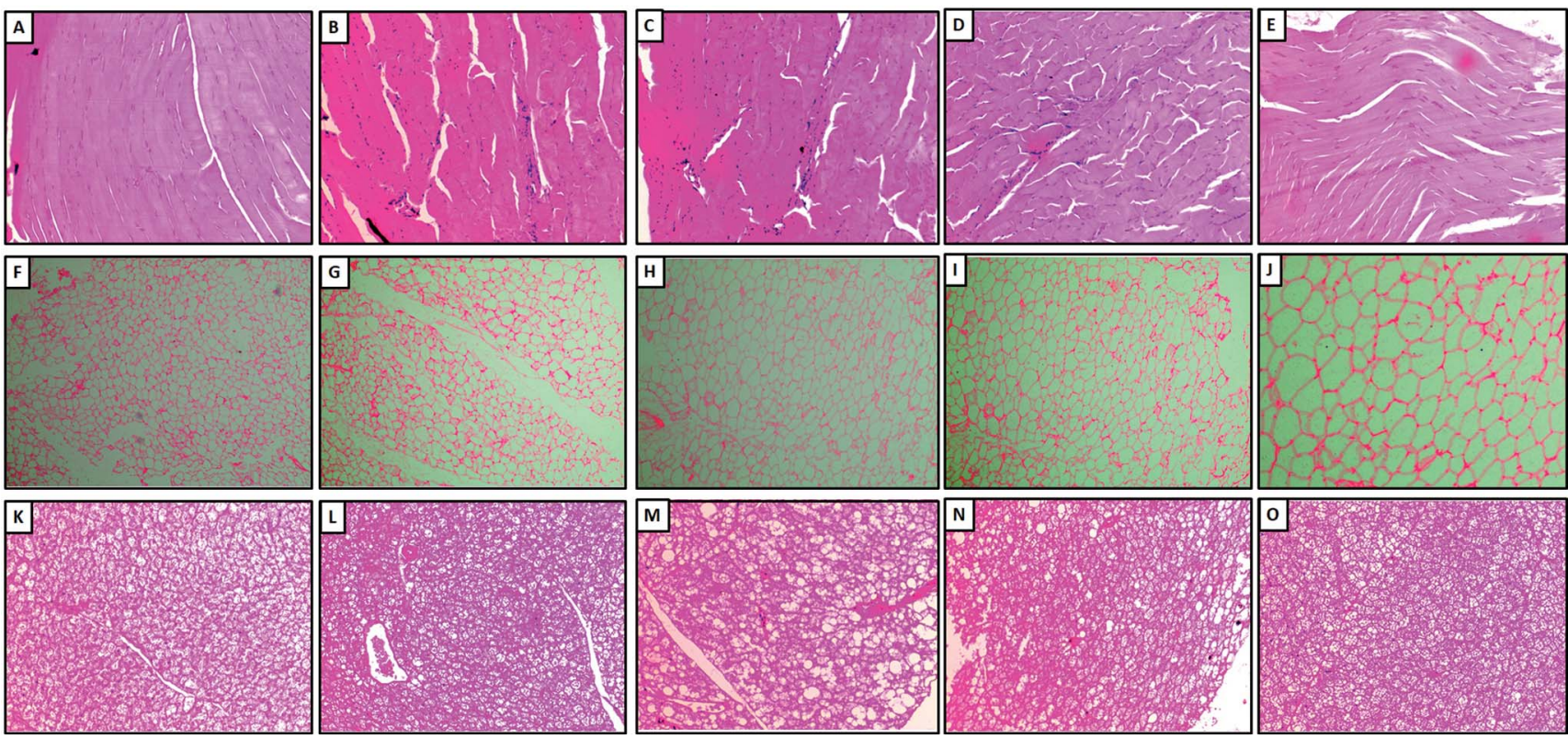

Fig. 3 The effects of LMWGAL-TF against HFD-induced histological alterations in skeletal muscle (A-E), white adipose tissue (F-J) and brown adipose tissue (K-O) of mice. Representative photomicrographs of tissues from LFD (A, F and K), HFD (B, G and L), LMWGAL-TF (30 mg kg ${ }^{-1}$ ) (C, $H$ and M), LMWGAL-TF $\left(60 \mathrm{mg} \mathrm{kg}^{-1}\right)(\mathrm{D}, \mathrm{I}$ and $\mathrm{N})$ and LMWGAL-TF $\left(100 \mathrm{mg} \mathrm{kg}^{-1}\right)(\mathrm{E}, \mathrm{J}$ and O). (H\&E stain at $40 \times)$. 


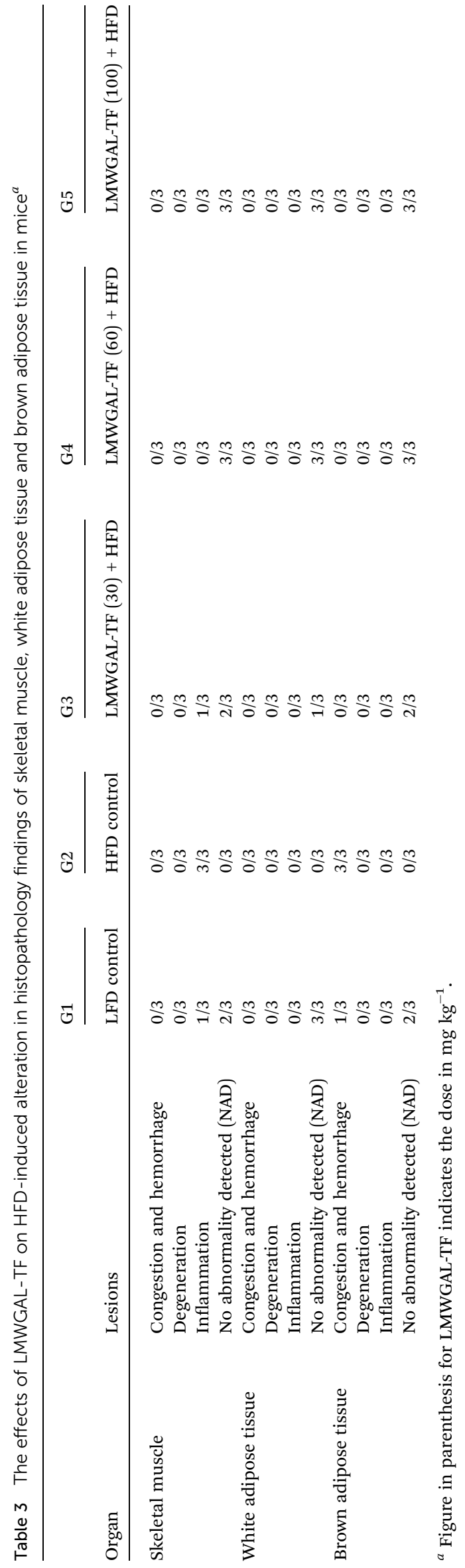

3.11 The effects of LMWGAL-TF on the HFD induced histological alterations in the liver tissue of mice

During necropsy, the gross examination of the livers of the LFD mice showed that they were reddish, smooth and lustrous on the surface. In contrast, the livers of the HFD mice were enlarged with rounded edges, and a pale appearance suggested the development of a fatty liver (steatosis) and steatohepatitis. Histopathological analysis of LFD mice showed the normal liver architecture (Fig. 4A), whereas HFD mice showed severe intrahepatic fat vacuoles (steatosis), which are evident in almost the majority of hepatic cells (Fig. 4B). The steatosis score was significantly higher $(p<0.05)$ in the HFD mice as compared to the LFD mice (Fig. 4F). The histological analysis of the livers of the mice administered LMWGAL-TF revealed an overall histological improvement of steatosis and inflammation (Fig. 4C-E). Rats treated with LMWGAL-TF (100 $\mathrm{mg} \mathrm{kg}^{-1}$ ) showed marked protection against the development of steatosis and inflammation, revealed by a marked reduction in lipid storage in hepatocytes (Fig. 4E). It also significantly inhibited $(p<0.05)$ the steatosis score when compared with the HFD mice (Fig. $4 \mathrm{~F}$ ).

\subsection{The effects of LMWGAL-TF on Cu-As-induced alteration in oxidative stress in skeletal muscle and brown adipose tissue}

The incubation of mitochondria with Cu-As showed significant elevation $(p<0.001)$ in the levels of LPO and PCO in skeletal muscle as well as in brown adipose tissue as compared to the normal group. However, these elevated levels of LPO and PCO were significantly decreased $(p<0.001)$ in the skeletal muscle and brown adipose tissue of the LMWGAL-TF $\left(1,2,4\right.$ and $\left.6 \mathrm{mg} \mathrm{mL}^{-1}\right)$ treated the group as compared the $\mathrm{Cu}$-As control group. There was a significant decrease $(p<0.001)$ in the levels of GSH, GR, GPx, ICDH, and $\alpha-\mathrm{KGDH}$ in the mitochondria of skeletal muscle and brown adipose tissue incubated with $\mathrm{Cu}$-As as compared to the normal group. These Cu-As-induced decreased levels of GSH, GR, GPx, ICDH and $\alpha-\mathrm{KGDH}$ in the mitochondria of skeletal muscle, and brown adipose tissue were significantly increased ( $p$ $<0.001)$ by LMWGAL-TF $\left(1,2,4\right.$ and $\left.6 \mathrm{mg} \mathrm{mL}^{-1}\right)$ coadministration as compared to the $\mathrm{Cu}$-As control group (Table 4).

\subsection{The effects of LMWGAL-TF on the Cu-As-induced alteration in mitochondrial swelling}

The incubation of mitochondria with $\mathrm{Cu}$-As caused mitochondrial dysfunction, which is depicted in Fig. 5A, as studied through scanning electron microscopy. Skeletal muscle and brown adipose tissue mitochondrial tissue from the normal group depicted the normal architecture without any aberrations. The skeletal muscle and brown adipose tissue mitochondria treated with $\mathrm{Cu}$-As control group showed a perforated surface with convoluted membranes. Moreover, these mitochondria were markedly contracted with large membrane blebs covering the mitochondrial surface. There was a decrease in the extent of absorbance of the skeletal muscle as well as brown adipose tissue mitochondria incubated with $\mathrm{Cu}-\mathrm{As}$ as compared to the normal group. These copper ascorbate-induced changes 

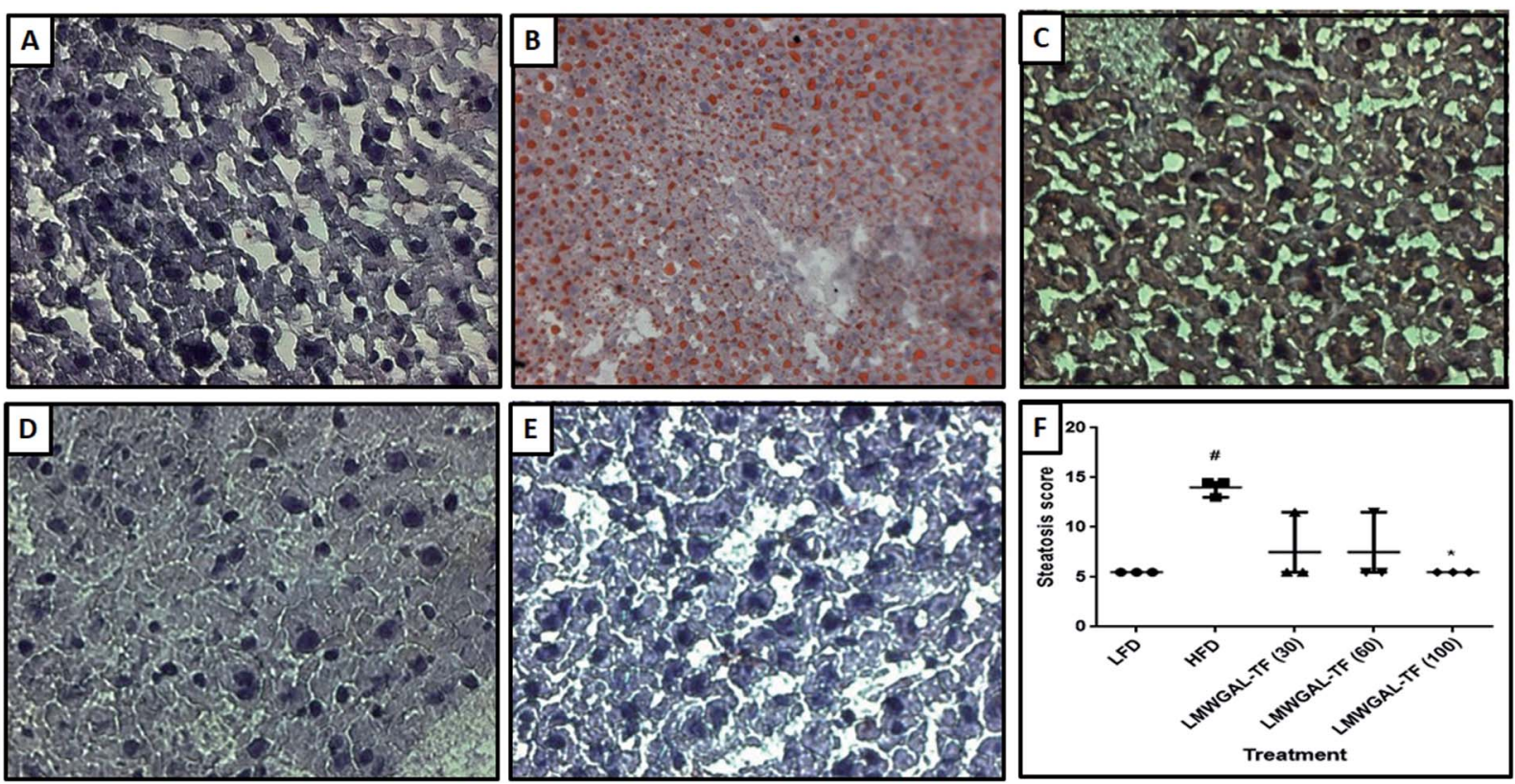

Fig. 4 The effects of LMWGAL-TF against HFD-induced histological alterations in the liver tissue of mice. Representative photomicrographs of tissues from LFD (A), HFD (B), LMWGAL-TF $\left(30 \mathrm{mg} \mathrm{kg}^{-1}\right)(\mathrm{C})$, LMWGAL-TF $\left(60 \mathrm{mg} \mathrm{kg}^{-1}\right)$ (D), LMWGAL-TF (100 mg kg $\left.{ }^{-1}\right)(\mathrm{E})(\mathrm{Oil}-\mathrm{Red}-\mathrm{O}$ stain at $100 \times)$, and quantitative representation of steatosis score (F). Data expressed as the mean \pm range, analyzed using the Kruskal-Wallis nonparametric test followed by Dunn's multiple comparison test. * $p<0.05$ as compared to HFD group and ${ }^{\#} p<0.05$ as compared to LFD group. Figure in parenthesis for LMWGAL-TF indicates the dose in $\mathrm{mg} \mathrm{kg}^{-1}$

in the skeletal muscle and brown adipose tissue mitochondrial surface were prevented when the mitochondria were coincubated with LMWGAL-TF (4 $\left.\mathrm{mg} \mathrm{kg}^{-1}\right)$. The extent of absorbance was also found to be protected when these skeletal muscle and BAT mitochondria were co-incubated with LMWGAL-TF (4 $\left.\mathrm{mg} \mathrm{kg}^{-1}\right)$ (Fig. 5B and C).

\section{Discussion}

In the last few decades, the prevalence of obesity has increased significantly worldwide, leading to various health hazards including T2DM, cardiovascular disease, hypertension, cancer, metabolic syndrome, liver disease, etc. Furthermore, adipocytes have been considered as an important mediator for the physiological pathways of obesity. ${ }^{65}$ Thus, many treatment strategies target adipocytes for the management of metabolic disorders including obesity. In the present investigation, we have evaluated the potential of water-soluble low molecular weight galactomannans-based standardized fenugreek seeds extract (LMWGAL-TF) against the HFD-induced obesity in mice. The coadministration of LMWGAL-TF showed significant amelioration of HFD-induced obesity by the inhibition of upregulated mRNA levels of FASn, leptin, IL-6, and TRIP-Br2 in brown adipose tissue, TRIP-Br2 and leptin in epididymal fat, as well as FASn and IL-6 mRNA expression in the liver.

A linear relationship between dietary fat consumption and body weight has been well established ${ }^{66}$ and the administration of a high-fat enriched diet makes a significant contribution to obesity development; thus, the model in which animals are fed with HFD has been widely used to induce obesity. ${ }^{67}$ It has been reported that the chronic administration of a HFD results in increased body weight and the accumulation of visceral fat. ${ }^{68,69}$ Results from the present investigation are in line with the findings of the previous investigators, where the administration of a HFD for 12 weeks resulted in impaired body composition and increased visceral adiposity (epididymal and retroperitoneal fat-pad weights). However, the co-administration of LMWGAL-TF significantly inhibited the HFD-induced gain in the body weight of mice. The results of the present investigation are in accordance with the findings of the previous investigator, where the administration of galactomannan along with HFD halted the increase in body weight, which may be due to a decrease in food intake by virtue of its property of delayed gastric emptying. ${ }^{.0}$

There have been numerous reports that visceral fat is a key etiological factor in obesity leading to metabolic syndrome and dyslipidemia. ${ }^{71,72}$ The vicious effect of obesity results from increases in white and brown fat mass. ${ }^{73}$ The white adipose tissue (WAT) serves as is a crucial site for energy conversion, whereas brown adipose tissue (BAT) is a primary organ for heat production (thermogenesis). Thus, these two tissues are considered as important targets for promoting weight loss. Furthermore, macrophages are among the important components of adipose tissue and are responsible for a pro-inflammatory response (such as TNF- $\alpha$ and ILs) $;^{74}$ thus, visceral adipose tissue is affected by obesity-related oxido-inflammation stress. ${ }^{75}$ In our study, HFD administration caused a significant increase in both WAT and BAT in HFD control mice, whereas the co-administration of LMWGAL-TF significantly reduced WAT and BAT mass, which may be due to its antioxidant and anti-inflammatory properties. 


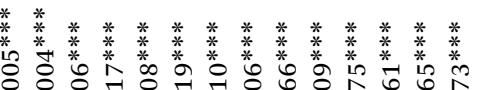

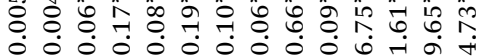
$\mathrm{H}+\mathrm{H} H+\mathrm{H} H+\mathrm{H} H \mathrm{H} H+\mathrm{H} H$ 숭 눙 ঠั

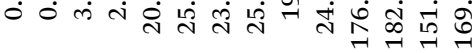

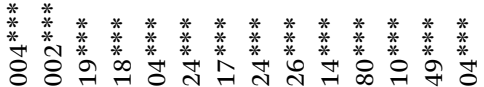

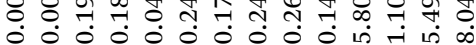 $H+H+H+H+H+H+H+H+H$ ఇ $\infty$ ○}

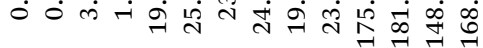

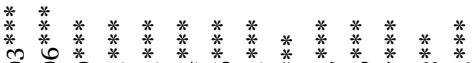

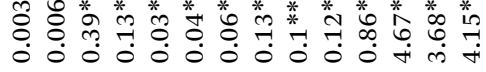
$H+H+H+H+H+H+H+H+H$ ๓

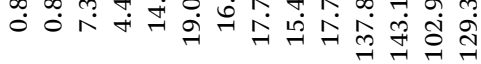

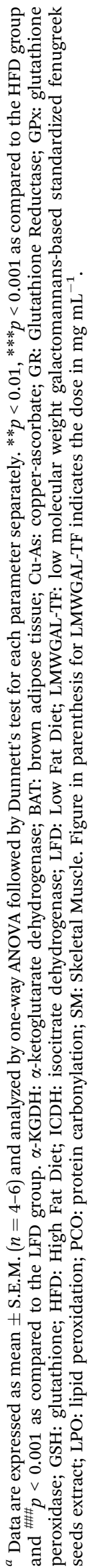

The circulating serum lipids, predominantly triglycerides and cholesterol are considered as important biomarkers for the development of obesity and metabolic disorders. An elevated level of triglycerides in adipose tissue results in an imbalance in lipid homeostasis, which in turn causes lipid metabolism disorder, i.e., dyslipidemia. ${ }^{76}$ It has been well documented that tight dietary control helps to reduce the elevated levels of triglycerides in patients with hypertriglyceridemia but only to a limited extent. ${ }^{77}$ Furthermore, prominent therapies such as Vytorin (Ezetimibe and Simvastatin) and Zetia (Ezetimibe) possess lipid-lowering potential, but they have failed to decrease the incidence of heart disease. ${ }^{78}$ However, many herbal drugs such as boswellia, ginger, and ginseng showed prominent antihyperlipidemic effects without any consequences of heart disease. ${ }^{79}$ In the present investigation, the co-administration of LMWGAL-TF significantly attenuated the HFD-induced alterations in serum lipid levels. Earlier studies have suggested that when both mice and patients with elevated lipid profiles were supplemented with fenugreek seeds, they showed significant improvement in plasma lipids and decreased fat deposition. ${ }^{80-82}$ Furthermore, the administration of galactomannans is associated with reduced levels of plasma triglycerides, total cholesterol, and LDL-cholesterol. ${ }^{83}$ The findings of the present investigation suggest that the presence of galactomannan-based standardized fenugreeks seed extract is attributed to its hypolipidemic effect.

In the past, researchers have underlined the correlation between oxidative stress and obesity. ${ }^{84,85}$ Mitochondria serve as power centers and centers for energy metabolism in cells; ${ }^{86}$ thus, aberrations in mitochondria cause the generation of vicious reactive oxygen species (ROS), which leads to cellular damage. ${ }^{87}$ It has been well established that elevated ROS can lead to various pathological conditions including metabolic disorders and obesity. Additionally, it has been clinically proven that elevated levels of lipid peroxide enhance oxidative stress in patients with metabolic syndrome and obesity. ${ }^{88}$ The chronic administration of a HFD is associated with elevated mitochondria oxidative stress and ROS. ${ }^{6}$ Peroxidation of the biomembrane phospholipids and the carbonylation of several proteins are the major biochemical consequences of oxidative stress. ${ }^{89}$ In our investigation, both of these parameters, i.e., lipid peroxidation and protein carbonylation, were significantly protected from oxidative stress-induced alterations when coadministered with LMWGAL-TF.

Reduced glutathione (GSH), the major non-protein sulfhydryl tripeptide acts as a major defense line for the maintenance of the appropriate mitochondrial redox environment. It also avoids or repairs oxidative stress-induced lipid and protein modifications that cause mitochondrial dysfunction and cell death. The significance of mitochondrial GSH is not only based on its abundance, but also on its versatility to counteract hydrogen peroxide, lipid hydroperoxides, or xenobiotics, mainly as a cofactor of enzymes such as glutathione peroxidase. ${ }^{90}$ The withdrawal of the excessive accumulation of hydrogen peroxide generated by the increased activity of mitochondrial $\mathrm{Mn}$ superoxide dismutase disproportionate to the generated paramagnetic superoxide anion radical through GSH is mediated by glutathione peroxidase. ${ }^{90}$ To maintain equilibrium in the GSH 


\section{A}
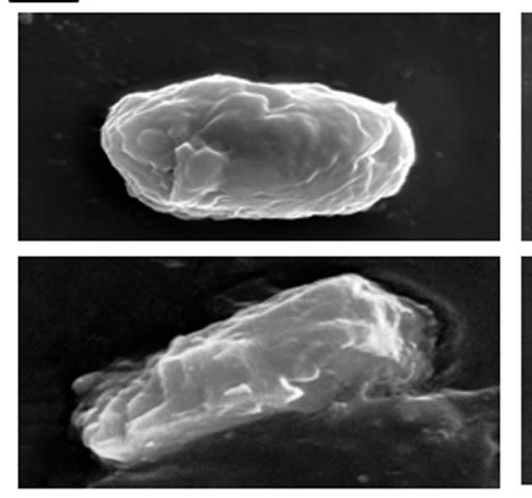

CuAs Control
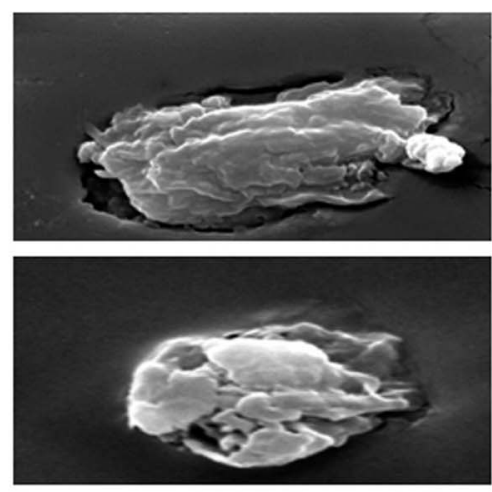

LMWGAL-TF (4) + CuAs
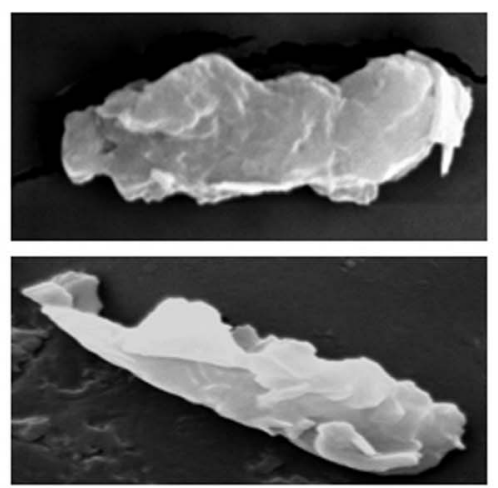

Skeletal muscle

Brown

Adipose

tissue

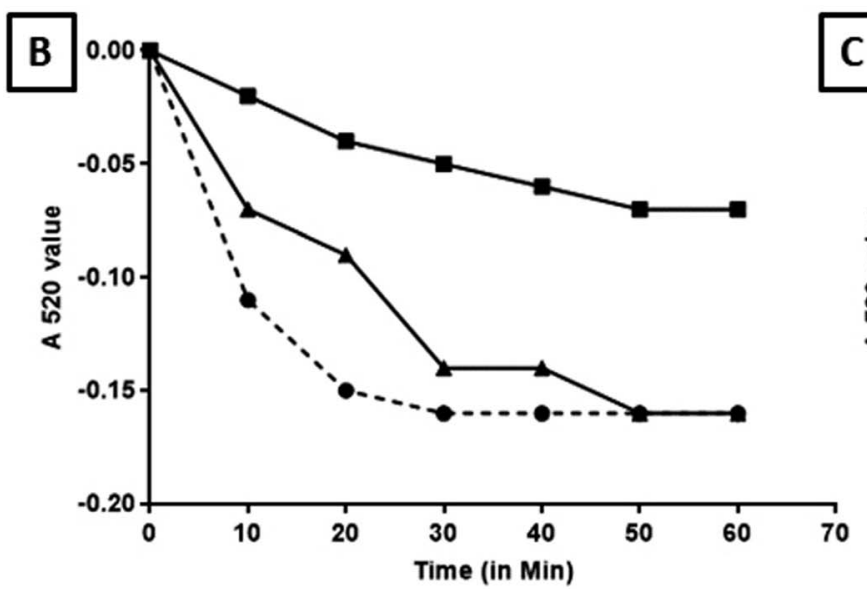

Normal
CuAs Control

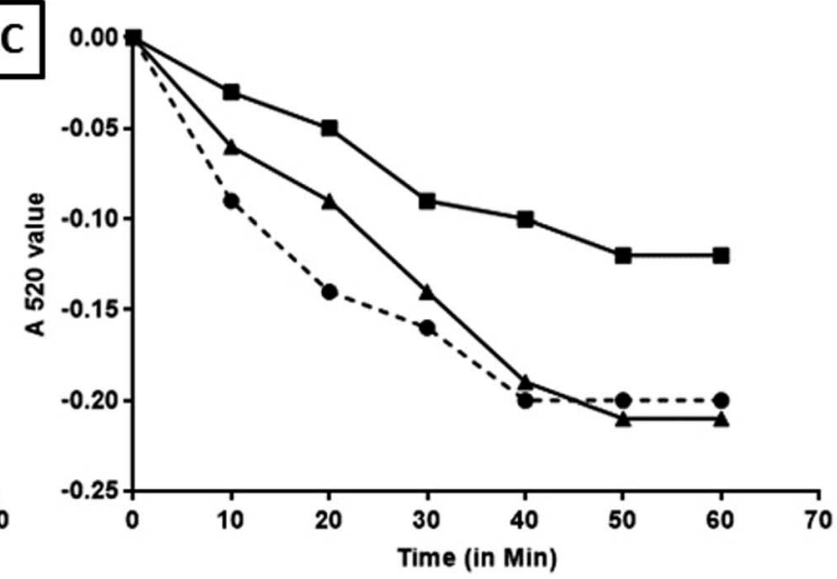

LMWGAL-TF (4) + CUAS

Fig. 5 The effects of LMWGAL-TF against Cu-As-induced swelling of skeletal muscle and brown adipose tissue mitochondria in goat tissues. Photomicrographs of scanning electron micrographs of the surface of single mitochondria from a group of skeletal muscle and brown adipose tissue (A); the extent of absorbance of the mitochondria in skeletal muscle (B), and the extent of absorbance of the mitochondria in brown adipose tissue $(C)$. Figure in parenthesis for LMWGAL-TF indicates the dose in $\mathrm{mg} \mathrm{mL}^{-1}$.

level, another enzyme, glutathione reductase, synthesizes GSH using NADPH (nicotinamide adenine dinucleotide phosphate) as the donor of the hydrogen atom. The significant decrease in glutathione peroxidase, glutathione reductase and GSH levels in $\mathrm{Cu}$-ascorbate incubated goat mitochondria indicates the oxidative damage of mitochondria. However, the coadministration of LMWGAL-TF significantly protects these antioxidant enzymes from $\mathrm{Cu}$-As-induced oxidative stress.

ICDH is a crucial enzyme in the cellular defense against oxidative damage as it provides NADPH in the mitochondria, which is needed for the regeneration of mitochondrial GSH or thioredoxin. The alpha-ketoglutarate dehydrogenase ( $\alpha$-KGDH) enzyme has been reported to associate with sensing oxidative stress and promoting antioxidant defense. ${ }^{91}$ Elevated levels of ROS cause the oxidation of thiol groups in $\mathrm{KGDH}$ resulting in the inactivation of this enzyme complex. Thus, the activation of $\mathrm{KGDH}$ would help to ameliorate oxidative stress. Hence, KGDH serves as an essential tool against ROS. ${ }^{92}$ In the present investigation, $\mathrm{KGDH}$ was oxidized during the Cu-ascorbate treatment, whereas the incubation of goat mitochondria with LMWGAL-TF significantly restored the activity of KGDH.

Many studies indicate that inflammation occurs due to an imbalance between the pro- and anti-inflammatory cytokines that play a vital role in etiopathogenesis in obesity.93,94 Elevated oxidative stress and impaired blood lipids are responsible for the release of pro-inflammatory cytokines (such as TNF- $\alpha$ and ILs) directly into primary adipocytes and macrophages..$^{95,96}$ It has been well reported that hypertrophy in adipocyte cells result in macrophage infiltration and the increased production of ROS as well as proinflammatory cytokines in obese conditions; ${ }^{97,98}$ thus, several lines of evidence suggest the role of pro-inflammatory cytokines in regulating obesity ${ }^{99,100}$ Studies carried out by various researchers have described the role of inflammation as an important contributor to obesity in HFD mice. ${ }^{\mathbf{1 0 1 - 1 0 3}}$ It has been reported that inflammation mainly affects the adipocytes in HFD mice that release the proinflammatory cytokines into circulation, including TNF- $\alpha$, ILs, and chemokines, leading to T2DM and obesity. ${ }^{103,104}$ The T2DM patient is also associated with the similar condition of elevated 
levels of pro-inflammatory cytokines including TNF- $\alpha$, IL-1 $1 \beta$, and IL- $6 .{ }^{105}$ Elevated levels of circulatory TNF- $\alpha$ in the HFD mice can be regarded as a potential mechanism leading to obesity. It has been reported that TNF- $\alpha$ inhibited FFA uptake, lipoprotein lipase expression and various proteins responsible for glyceroneogenesis. ${ }^{106,107}$ It also plays a crucial role in leptin production. ${ }^{108,109}$ In the present investigation, there was an increase in the levels of serum TNF- $\alpha$ in the HFD control mice but it was non-significant, which might be due to the minimal participation of the TNF$\alpha$ receptor signaling pathways under the current settings. The coadministration of LMWGAL-TF also did not show any alterations in the level of serum TNF- $\alpha$.

In obese individuals, a cytokine such as IL-6 is known to contribute to the low-level systemic inflammation. ${ }^{\mathbf{1 1 0}}$ The elevated plasma free fatty acids activate NF- $\kappa \mathrm{B}$ (nuclear factor kappa-light-chain-enhancer of activated $\mathrm{B}$ cells) signaling, resulting in the induction of IL-6 expression. ${ }^{111}$ Furthermore, macrophages present in adipose tissue demonstrate the presence of about $30 \%$ of circulating IL- 6 in obese conditions. ${ }^{74}$ Also, a good correlation between adipocyte size and serum IL-6 levels has been proven clinically. ${ }^{112}$ It has been reported that the infiltrated monocytes/macrophages are associated with high level of IL-6 after injury. ${ }^{\mathbf{1 1 3}}$ There are many studies that have determined the size of the visceral adipocyte in an animal model of HFD induced obesity; ${ }^{\mathbf{1 1 4}, \mathbf{1 1 5}}$ thus, in the present investigation, elevated levels of IL-6 in HFD-mice reflect the onset of inflammation in the adipocytes. However, the coadministration of LMWGAL-TF resulted in the decreased weight of WAT and BAT along with the reduced levels of serum IL-6. Additionally, the up-regulated IL-6 mRNA expression in adipose tissue and liver after HFD administration was also significantly down-regulated by LMWGAL-TF. Thus, the inhibitory potential of LMWGAL-TF against HFD-induced elevated IL6 mRNA expression may be responsible for decreased macrophage infiltration.

Leptin, an adipocyte-produced hormone, plays a vital role in the regulation of food intake and energy expenditure. ${ }^{116}$ The elevated levels of leptin in serum serve as an essential indicator of obesity. ${ }^{117}$ Alteration in the functioning of adipose tissue results in hyperlipidemia that is associated with an elevated level of plasma lipid in obese children. ${ }^{118}$ Previous researchers have demonstrated that HFD-induced mice are associated with elevated circulatory leptin levels as well as up-regulated mRNA expression of leptin in epididymal fat and brown adipose tissue. ${ }^{119,120}$ Also, the obese subjects showed elevated plasma leptin levels. ${ }^{121}$ Our results are consistent with the findings of previous investigators, where the chronic administration of the HFD is associated with elevated serum leptin levels and upregulated mRNA expression of leptin in brown adipose tissue and epididymal fat. ${ }^{\mathbf{1 1 9 , 1 2 0}}$ Our results also reveal that these circulatory leptin levels are associated with elevated ROS production, which is in accordance with findings in the obese subjects. ${ }^{\mathbf{1 2 2}}$ However, this up-regulated level of leptin mRNA was significantly attenuated by the LMWGAL-TF co-administration, which might be via the modulation of oxidative stress, indicating its possible role in ameliorating HFD induced obesity.
Ghrelin is another important gastrointestinal, and endocrine peptide that plays an important role in the suppression of hunger and long-term regulation of body weight and food intake associated with obesity. ${ }^{123,124}$ It has been reported that a change in body weight is associated with ghrelin receptor sensitivity; thus, ghrelin is an essential modulator of body mass index (BMI). ${ }^{125}$ Ghrelin receptor modulation also leads to the suppression of proinflammatory cytokine release. ${ }^{\mathbf{1 2 6}}$ A clinical study revealed that obese patients were also associated with altered levels of plasma ghrelin. ${ }^{\mathbf{1 2 4}}$ In the present study, the chronic administration of HFD showed altered plasma ghrelin in C57BL/6 mice. However, the co-administration of LMWGALTF failed to produce any significant changes in these HFDinduced alterations in plasma ghrelin levels.

An increase in the fat mass is characterized by the elevated number and size of adipocytes in adipose tissue that is differentiated from preadipocytes. During this differentiation, lipogenesis occurrs in adipocytes where free fatty acids (FFAs) are stored in the form of triglycerides. ${ }^{116}$ It has been reported that fatty acid synthase (FASn), a lipogenesis regulating gene, plays a vital role in the fatty acids synthesis. ${ }^{127}$ Activation of FASn expression may result in elevated fat accumulation in brown adipose tissue and the liver. ${ }^{\mathbf{1 1 7}}$ Administration of the HFD results in the up-regulation of FASn mRNA expression in the brown adipose tissue and the liver of mice, which has been previously documented. ${ }^{\mathbf{1 2 8}}$ In the present study, we also confirmed the increase in the mRNA expression of FASn in the HFD control mice in BAT tissue and the liver as compared to the LFD control mice. The co-administration of LMWGAL-TF showed significant down-regulation of FASn mRNA expression in BAT tissue as well as the liver. The down-regulation of FASn by LMWGAL-TF was also evidenced by the decrease in the levels of serum triglyceride. The results of the present investigation are in accordance with the findings of previous researchers ${ }^{\mathbf{1 9 , 1 2 9}}$ where the administration of fenugreek seed extract was also associated with inhibition of triglyceride synthesis.

TRIP-Br2 (transcriptional regulator interacting with the PHDbromodomain 2, also called SERTAD2), is a member of the $\beta$ adrenergic receptor family that regulates fat lipolysis in white and brown adipose tissue. ${ }^{\mathbf{1 3 0}}$ Its expression in adipose tissues is correlated with the development of diet-induced obesity, whereas its down-regulation results in the enhanced lipolysis of adipocytes, thermogenesis and oxidative metabolism and thus inhibits diet-induced obesity. ${ }^{\mathbf{1 3 1}}$ Clinically, it has been proven that obesity is associated with the upregulated expression of TRIP-Br2 in visceral fat, and its transcriptional co-regulation serves as a new approach to treat obesity and its related disorders. ${ }^{65,131}$ It has been suggested that down-regulation of TRIP-Br2 enhances fasting-stimulated $\beta$-adrenergic-regulated lipolytic activities. ${ }^{\mathbf{1 3 1}}$ Our data show that the mRNA expression of TRIP-Br2 was significantly higher in BAT tissue from HFD-treated mice but remained almost unchanged in epididymal fat, which may be due to differences in sensitivity to $\beta$-adrenergic stimulation. However, the down-regulation of TRIP-Br2 mRNA expression was observed in the BAT tissue after the co-administration of LMWGAL-TF, which may increase lipid mobilization. 


\section{Conclusion}

The low molecular weight galactomannans-based standardized fenugreek seed extract (LMWGAL-TF) shows potential against HFD-induced obesity in mice. This suppressive effect on adipogenesis may be orchestrated via multiple mechanisms including the down-regulation of FASn, IL-6, leptin, and TRIP-Br2. Therefore, our present study suggests that LMWGAL-TF may serve as a healthcare product or dietary supplement to ameliorate dietinduced obesity and related metabolic disorders.

\section{Conflicts of interest}

The authors have declared that they have no conflict of interest.

\section{Abbreviations}

$\begin{array}{ll}\alpha-\text { KGDH } & \text { Alpha-ketoglutarate dehydrogenase } \\ \text { BAT } & \text { Brown adipose tissue } \\ \text { BMI } & \text { Body Mass Index } \\ \text { FAS } & \text { Fatty Acid Synthase } \\ \text { GAL } & \text { Galactomannans } \\ \text { GSH } & \text { Glutathione } \\ \text { HDL } & \text { High-Density Lipoprotein } \\ \text { HFD } & \text { High Fat Diet } \\ \text { ICDH } & \text { Isocitrate dehydrogenase } \\ \text { ILS } & \text { Interleukins } \\ \text { LDL } & \text { Low-Density Lipoprotein } \\ \text { LFD } & \text { Low-Fat Diet } \\ \text { LMWGAL- } & \text { Low molecular weight galactomannans-based } \\ \text { TF } & \text { standardized fenugreek seeds extract } \\ \text { LPO } & \text { Lipid Peroxidation } \\ \text { PCO } & \text { Protein carbonylation } \\ \text { ROS } & \text { Reactive Oxygen Species } \\ \text { RT-PCR } & \text { Reverse transcription polymerase chain reaction } \\ \text { TNF- } \alpha & \text { Tumor Necrosis Factor- } \alpha \\ \text { TRIP-Br2 } & \text { Transcriptional regulator interacting with the } \\ & \text { PHD-bromodomain 2 } \\ \text { WAT } & \text { White adipose tissue }\end{array}$

\section{Acknowledgements}

The authors would like acknowledge Sunil Bhaskaran, MD, Indus Biotech Private Limited, Pune, India for providing necessary facilities to carry out the study.

\section{References}

1 S. Wild, G. Roglic, A. Green, R. Sicree and H. King, Diabetes Care, 2004, 27, 1047-1053.

2 C. M. Steppan, S. T. Bailey, S. Bhat, E. J. Brown, R. R. Banerjee, C. M. Wright, H. R. Patel, R. S. Ahima and M. A. Lazar, Nature, 2001, 409, 307-312.

3 World Health Organization, Obesity and overweight. Fact sheet No. 311, 2016, http:/www.who.int/mediacentre/ factsheets/fs311/en/, (accessed February, 2018).
4 P. Zimmet, K. G. Alberti and J. Shaw, Nature, 2001, 414, 782787.

5 L. E. Fridlyand and L. H. Philipson, Curr. Diabetes Rev., 2006, 2, 241-259.

6 K. E. Wellen and G. S. Hotamisligil, J. Clin. Invest., 2005, 115, 1111-1119.

7 B. Antuna-Puente, B. Feve, S. Fellahi and J. P. Bastard, Diabetes Metab., 2008, 34, 2-11.

8 M. Kamigaki, S. Sakaue, I. Tsujino, H. Ohira, D. Ikeda, N. Itoh, S. Ishimaru, Y. Ohtsuka and M. Nishimura, Biochem. Biophys. Res. Commun., 2006, 339, 624-632.

9 Y. Uchida, K. Ohba, T. Yoshioka, K. Irie, T. Muraki and Y. Maru, J. Biol. Chem., 2004, 279, 4075-4083.

10 E. D. Rosen, C. J. Walkey, P. Puigserver and B. M. Spiegelman, Genes Dev., 2000, 14, 1293-1307.

11 M. Fasshauer and R. Paschke, Diabetologia, 2003, 46, 15941603.

12 R. A. Hammond and R. Levine, Diabetes Metab. Syndr. Obes., 2010, 3, 285-295.

13 C. T. De Souza, E. P. Araujo, S. Bordin, R. Ashimine, R. L. Zollner, A. C. Boschero, M. J. Saad and L. A. Velloso, Endocrinology, 2005, 146, 4192-4199.

14 K. A. Posey, D. J. Clegg, R. L. Printz, J. Byun, G. J. Morton, A. Vivekanandan-Giri, S. Pennathur, D. G. Baskin, J. W. Heinecke, S. C. Woods, M. W. Schwartz and K. D. Niswender, Am. J. Physiol.: Endocrinol. Metab., 2009, 296, E1003-E1012.

15 G. S. Hotamisligil and E. Erbay, Nat. Rev. Immunol., 2008, 8, 923-934.

16 G. Fantuzzi, J. Allergy Clin. Immunol., 2005, 115, 911-919, quiz 920.

17 K. M. McTigue, R. Harris, B. Hemphill, L. Lux, S. Sutton, A. J. Bunton and K. N. Lohr, Ann. Intern. Med., 2003, 139, 933-949.

18 R. J. Rodgers, M. H. Tschop and J. P. Wilding, Dis. Models Mech., 2012, 5, 621-626.

19 A. Garg and V. Simha, J. Clin. Endocrinol. Metab., 2007, 92, 1581-1589.

20 T. Matsui, I. A. Ogunwande, K. J. Abesundara and K. Matsumoto, Mini-Rev. Med. Chem., 2006, 6, 349-356.

21 J. E. Lambert, J. A. Parnell, J. M. Tunnicliffe, J. Han, T. Sturzenegger and R. A. Reimer, Clin. Nutr., 2017, 36, 126-133.

22 E. A. Datau, R. Wardhana, E. E. Surachmanto, K. Pandelaki, J. A. Langi and A. Fias, Acta Med. Indones., 2010, 42, 130134.

23 F. Di Pierro, A. B. Menghi, A. Barreca, M. Lucarelli and A. Calandrelli, Altern. Med. Rev., 2009, 14, 154-160.

24 H. Wang, Y. Wen, Y. Du, X. Yan, H. Guo, J. A. Rycroft, N. Boon, E. M. Kovacs and D. J. Mela, Obesity, 2010, 18, 773-779.

25 J. E. Oben, D. M. Enyegue, G. I. Fomekong, Y. B. Soukontoua and G. A. Agbor, Lipids Health Dis., 2007, 6, 4 .

26 I. Raskin, D. M. Ribnicky, S. Komarnytsky, N. Ilic, A. Poulev, N. Borisjuk, A. Brinker, D. A. Moreno, C. Ripoll, N. Yakoby, 
J. M. O'Neal, T. Cornwell, I. Pastor and B. Fridlender, Trends Biotechnol., 2002, 20, 522-531.

27 D. J. Jenkins, G. S. Wong, R. Patten, J. Bird, M. Hall, G. C. Buckley, V. McGuire, R. Reichert and J. A. Little, Am. J. Clin. Nutr., 1983, 38, 567-573.

28 M. So, M. P. Gaidhu, B. Maghdoori and R. B. Ceddia, Lipids Health Dis., 2011, 10, 99.

29 R. S. Surwit, C. M. Kuhn, C. Cochrane, J. A. McCubbin and M. N. Feinglos, Diabetes, 1988, 37, 1163-1167.

30 S. Collins, T. L. Martin, R. S. Surwit and J. Robidoux, Physiol. Behav., 2004, 81, 243-248.

31 S. Chang, B. Graham, F. Yakubu, D. Lin, J. C. Peters and J. O. Hill, Am. J. Physiol., 1990, 259, R1103-R1110.

32 M. A. Micallef and M. L. Garg, J. Nutr. Biochem., 2009, 20, 927-939.

33 A. Mullaicharam, D. Geetali and M. Uma, Res. J. Pharm., Biol. Chem. Sci., 2013, 4, 1304-1313.

34 M. M. Al-Oqail, N. N. Farshori, E. S. Al-Sheddi, J. Musarrat, A. A. Al-Khedhairy and M. A. Siddiqui, Asian Pac. J. Cancer Prev., 2013, 14, 1829-1832.

35 E. Basch, C. Ulbricht, G. Kuo, P. Szapary and M. Smith, Altern. Med. Rev., 2003, 8, 20-27.

36 T. Handa, K. Yamaguchi, Y. Sono and K. Yazawa, Biosci., Biotechnol., Biochem., 2005, 69, 1186-1188.

37 A. Mandegary, M. Pournamdari, F. Sharififar, S. Pournourmohammadi, R. Fardiar and S. Shooli, Food Chem. Toxicol., 2012, 50, 2503-2507.

38 A. D. Kandhare, S. L. Bodhankar, V. Mohan and P. A. Thakurdesai, Chem.-Biol. Interact., 2015, 237, 151-165.

39 T. Raghuram, R. Sharma, B. Sivakumar and B. Sahay, Phytother. Res., 1994, 8, 83-86.

40 K. Srinivasan, Int. J. Food Sci. Nutr., 2005, 56, 399-414.

41 H. Kamble, A. D. Kandhare, S. Bodhankar, V. Mohan and P. Thakurdesai, Biomed. Aging Pathol., 2013, 3, 145-151.

42 U. Aswar, V. Mohan, S. Bhaskaran and L. Bodhankar, Pharmacologyonline, 2008, 56-65.

43 A. D. Kandhare, S. L. Bodhankar, V. Mohan and P. A. Thakurdesai, J. Appl. Pharm. Sci., 2015, 5, 35-45.

44 R. Sharma, Nutr. Res., 1986, 6, 1353-1364.

45 D. J. Jenkins, T. M. Wolever, R. H. Taylor, D. Reynolds, R. Nineham and T. D. Hockaday, Br. Med. J., 1980, 280, 1353-1354.

46 R. M. Fairchild, P. R. Ellis, A. J. Byrne, S. D. Luzio and M. A. Mir, Br. J. Nutr., 1996, 76, 63-73.

47 J. P. Sels, J. A. Flendrig and T. J. Postmes, Br. J. Nutr., 1987, 57, 177-183.

48 D. J. Jenkins, R. H. Taylor, T. M. Wolever, S. Bacon, T. D. Hockaday and D. J. Reynolds, Br. Med. J., 1980, 281, 62.

49 C. Poole, B. Bushey, C. Foster, B. Campbell, D. Willoughby, R. Kreider, L. Taylor and C. Wilborn, J. Int. Soc. Sports Nutr., 2010, 7, 34 .

50 S. L. Bodhankar, A. Kandhare, V. Mohan and P. A. Thakudesai, Paper Presented at: XXXIII Annual Conference of Society of Toxicology (STOX), Mathura, India, 2013.
51 E. M. Brunt, C. G. Janney, A. M. Di Bisceglie, B. A. Neuschwander-Tetri and B. R. Bacon, Am. J. Gastroenterol., 1999, 94, 2467-2474.

52 D. E. Kleiner, E. M. Brunt, M. Van Natta, C. Behling, M. J. Contos, O. W. Cummings, L. D. Ferrell, Y. C. Liu, M. S. Torbenson, A. Unalp-Arida, M. Yeh, A. J. McCullough, A. J. Sanyal and N. Nonalcoholic Steatohepatitis Clinical Research, Hepatology, 2005, 41, 1313-1321.

53 J. F. Hare, E. Ching and G. Attardi, Biochemistry, 1980, 19, 2023-2030.

54 M. Dutta, A. K. Ghosh, V. Mohan, P. Mishra, V. Rangari, A. Chattopadhyay, T. Das, D. Bhowmick and D. Bandyopadhyay, J. Pharma Res., 2014, 8, 798-811.

55 M. Dutta, A. K. Ghosh, A. Basu, D. Bandyopadhyay and A. Chattopadhyay, Int. J. Pharm. Pharm. Sci., 2013, 5, 439447.

56 J. A. Buege and S. D. Aust, Methods Enzymol., 1978, 52, 302310.

57 R. L. Levine, J. A. Williams, E. R. Stadtman and E. Shacter, Methods Enzymol., 1994, 233, 346-357.

58 J. Sedlak and R. H. Lindsay, Anal. Biochem., 1968, 25, 192205.

59 D. E. Paglia and W. N. Valentine, J. Lab. Clin. Med., 1967, 70, 158-169.

60 A. K. Ghosh, E. Mitra, M. Dutta, D. Mukherjee, A. Basu, S. Firdaus, D. Bandyopadhyay and A. Chattopadhyay, Asian J. Pharm. Clin. Res., 2013, 6, 196-200.

61 G. Krohne-Ehrich, R. H. Schirmer and R. Untucht-Grau, Eur. J. Biochem., 1977, 80, 65-71.

62 M. J. Duncan and D. G. Fraenkel, J. Bacteriol., 1979, 137, 415-419.

63 A. P. Halestrap and A. M. Davidson, Biochem. J., 1990, 268, 153-160.

64 D. Mukherjee, A. K. Ghosh, M. Dutta, E. Mitra, S. Mallick, B. Saha, R. J. Reiter and D. Bandyopadhyay, J. Pineal Res., 2015, 58, 275-290.

65 Z.-H. Yang, H. Miyahara, J. Takeo and M. Katayama, Diabetol. Metab. Syndr., 2012, 4, 32.

66 D. B. West and B. York, Am. J. Clin. Nutr., 1998, 67, 505S$512 S$.

67 R. Buettner, K. G. Parhofer, M. Woenckhaus, C. E. Wrede, L. A. Kunz-Schughart, J. Scholmerich and L. C. Bollheimer, J. Mol. Endocrinol., 2006, 36, 485-501.

68 M. S. Gauthier, K. Couturier, A. Charbonneau and J. M. Lavoie, Int. J. Obes. Relat. Metab. Disord., 2004, 28, 1064-1071.

69 A. A. da Silva, J. J. Kuo, L. S. Tallam and J. E. Hall, Hypertension, 2004, 43, 383-387.

70 A. J. Evans, R. L. Hood, D. G. Oakenfull and G. S. Sidhu, Br. J. Nutr., 1992, 68, 217-229.

71 S. M. Grundy, J. I. Cleeman, S. R. Daniels, K. A. Donato, R. H. Eckel, B. A. Franklin, D. J. Gordon, R. M. Krauss, P. J. Savage, S. C. Smith Jr, J. A. Spertus and C. Fernando, Crit. Pathw. Cardiol., 2005, 4, 198-203.

72 Y. Matsuzawa, T. Funahashi and T. Nakamura, Ann. N. Y. Acad. Sci., 1999, 892, 146-154. 
73 L. H. Storlien, D. E. James, K. M. Burleigh, D. J. Chisholm and E. W. Kraegen, Am. J. Physiol., 1986, 251, E576-E583.

74 S. P. Weisberg, D. McCann, M. Desai, M. Rosenbaum, R. L. Leibel and A. W. Ferrante Jr, J. Clin. Invest., 2003, 112, 1796-1808.

75 M. M. Ibrahim, Obes. Rev., 2010, 11, 11-18.

76 C. H. Lee, P. Olson and R. M. Evans, Endocrinology, 2003, 144, 2201-2207.

77 A. Husing, I. Kabar and H. H. Schmidt, World J. Gastroenterol., 2016, 22, 3315-3324.

78 M. Mitka, J. Am. Med. Assoc., 2008, 299, 885-887.

79 H. Rouhi-Boroujeni, H. Rouhi-Boroujeni, E. Heidarian, F. Mohammadizadeh and M. Rafieian-Kopaei, $A R Y A$ Atheroscler., 2015, 11, 244-251.

80 F. M. Gregoire, Exp. Biol. Med., 2001, 226, 997-1002.

81 R. D. Sharma, T. C. Raghuram and N. S. Rao, Eur. J. Clin. Nutr., 1990, 44, 301-306.

82 O. Belguith-Hadriche, M. Bouaziz, K. Jamoussi, A. El Feki, S. Sayadi and F. Makni-Ayedi, J. Agric. Food Chem., 2010, 58, 2116-2122.

83 E. Ferrannini, E. J. Barrett, S. Bevilacqua and R. A. DeFronzo, J. Clin. Invest., 1983, 72, 1737-1747.

84 B. Westermann, J. Biol. Chem., 2008, 283, 13501-13505.

85 H. Chen, M. Vermulst, Y. E. Wang, A. Chomyn, T. A. Prolla, J. M. McCaffery and D. C. Chan, Cell, 2010, 141, 280-289.

86 M. Liesa, M. Palacin and A. Zorzano, Physiol. Rev., 2009, 89, 799-845.

87 C. H. Wang, C. C. Wang and Y. H. Wei, Ann. N. Y. Acad. Sci., 2010, 1201, 157-165.

88 I. Grattagliano, V. O. Palmieri, P. Portincasa, A. Moschetta and G. Palasciano, J. Nutr. Biochem., 2008, 19, 491-504.

89 A. Ayala, M. F. Munoz and S. Arguelles, Oxid. Med. Cell. Longevity, 2014, 2014, 360438.

90 M. Mari, A. Morales, A. Colell, C. Garcia-Ruiz and J. C. Fernandez-Checa, Antioxid. Redox Signaling, 2009, 11, 2685-2700.

91 Q. Shi, H. Xu, W. A. Kleinman and G. E. Gibson, Biochim. Biophys. Acta, Mol. Basis Dis., 2008, 1782, 229-238.

92 L. Tretter and V. Adam-Vizi, Philos. Trans. R. Soc. Lond., B, Biol. Sci., 2005, 360, 2335-2345.

93 R. Adabimohazab, A. Garfinkel, E. C. Milam, O. Frosch, A. Mangone and A. Convit, Inflammation, 2016, 39, 9941003.

94 U. J. Jung and M. S. Choi, Int. J. Mol. Sci., 2014, 15, 61846223.

95 R. A. DeFronzo and D. Tripathy, Diabetes Care, 2009, 32(suppl. 2), S157-S163.

96 G. S. Hotamisligil, Nature, 2006, 444, 860-867.

97 A. H. Berg and P. E. Scherer, Circ. Res., 2005, 96, 939-949.

98 J. I. Odegaard and A. Chawla, Nat. Clin. Pract. Endocrinol. Metab., 2008, 4, 619-626.

99 M. Jernas, J. Palming, K. Sjoholm, E. Jennische, P. A. Svensson, B. G. Gabrielsson, M. Levin, A. Sjogren, M. Rudemo, T. C. Lystig, B. Carlsson, L. M. Carlsson and M. Lonn, FASEB J., 2006, 20, 1540-1542.

100 N. R. Veillard, S. Steffens, F. Burger, G. Pelli and F. Mach, Arterioscler., Thromb., Vasc. Biol., 2004, 24, 2339-2344.
101 B. K. Cole, S. R. Keller, R. Wu, J. D. Carter, J. L. Nadler and C. S. Nunemaker, Hypertension, 2010, 55, 715-721.

102 P. Dandona, A. Aljada and A. Bandyopadhyay, Trends Immunol., 2004, 25, 4-7.

103 T. Kizaki, T. Maegawa, T. Sakurai, J.-e. Ogasawara, T. Ookawara, S. Oh-ishi, T. Izawa, S. Haga and H. Ohno, Biochem. Biophys. Res. Commun., 2011, 413, 454-459.

104 Y. Deng and P. E. Scherer, Ann. N. Y. Acad. Sci., 2010, 1212, E1-E19.

105 J. Pickup and M. Crook, Diabetologia, 1998, 41, 1241-1248.

106 H. Ruan and H. F. Lodish, Cytokine Growth Factor Rev., 2003, 14, 447-455.

107 S. E. Shoelson, J. Lee and A. B. Goldfine, J. Clin. Invest., 2006, 116, 1793-1801.

108 S. W. Coppack, Proc. Nutr. Soc., 2001, 60, 349-356.

109 P. Trayhurn and I. S. Wood, Biochem. Soc. Trans., 2005, 33, 1078-1081.

110 Z. Gao, A. Zuberi, M. J. Quon, Z. Dong and J. Ye, J. Biol. Chem., 2003, 278, 24944-24950.

111 J. Y. Yang, E. Moon, S. H. Nam and M. Friedman, J. Agric. Food Chem., 2012, 60, 7442-7449.

112 C. Maffeis, D. Silvagni, R. Bonadonna, A. Grezzani, C. Banzato and L. Tato, J. Pediatr., 2007, 151, 647-652.

113 C. Zhang, Y. Li, Y. Wu, L. Wang, X. Wang and J. Du, J. Biol. Chem., 2013, 288, 1489-1499.

114 J. O'Connell, L. Lynch, T. J. Cawood, A. Kwasnik, N. Nolan, J. Geoghegan, A. McCormick, C. O'Farrelly and D. O'Shea, PLoS One, 2010, 5, e9997.

115 R. Roberts, L. Hodson, A. L. Dennis, M. J. Neville, S. M. Humphreys, K. E. Harnden, K. J. Micklem and K. N. Frayn, Diabetologia, 2009, 52, 882-890.

116 T. Park, Evid.-Based Complementary Altern. Med., 2013, 2013.

117 L. Jiang, Q. Wang, Y. Yu, F. Zhao, P. Huang, R. Zeng, R. Z. Qi, W. Li and Y. Liu, PLoS One, 2009, 4, e6884.

118 A. C. Nicholson, D. P. Hajjar, X. Zhou, W. He, A. M. Gotto Jr and J. Han, Br. J. Pharmacol., 2007, 151, 807-815.

119 M. Sumiyoshi, M. Sakanaka and Y. Kimura, J. Nutr., 2006, 136, 582-587.

120 K. Tsuchiya, H. Sakai, N. Suzuki, F. Iwashima, T. Yoshimoto, M. Shichiri and Y. Hirata, Endocrinology, 2007, 148, 4548-4556.

121 R. E. Quiros-Tejeira, C. A. Rivera, T. T. Ziba, N. Mehta, C. W. Smith and N. F. Butte, J. Pediatr. Gastroenterol. Nutr., 2007, 44, 228-236.

122 S. Nakanishi, K. Yamane, N. Kamei, H. Nojima, M. Okubo and N. Kohno, Metabolism, 2005, 54, 194-199.

123 M. Kojima, H. Hosoda, Y. Date, M. Nakazato, H. Matsuo and K. Kangawa, Nature, 1999, 402, 656-660.

124 T. Shiiya, M. Nakazato, M. Mizuta, Y. Date, M. S. Mondal, M. Tanaka, S. Nozoe, H. Hosoda, K. Kangawa and S. Matsukura, J. Clin. Endocrinol. Metab., 2002, 87, 240-244.

125 V. P. Chen, Y. Gao, L. Geng and S. Brimijoin, Proc. Natl. Acad. Sci. U. S. A., 2017, 114, 10960-10965.

126 D. D. Taub, Cell. Immunol., 2008, 252, 1-6.

127 W. Gu, K.-A. Kim and D.-H. Kim, Biol. Pharm. Bull., 2012, 36, 102-107. 
128 S. J. Wakil, J. K. Stoops and V. C. Joshi, Annu. Rev. Biochem., 1983, 52, 537-579.

129 M. V. Vijayakumar, V. Pandey, G. C. Mishra and M. K. Bhat, Obesity, 2010, 18, 667-674.

130 K. El Hadri, B. Feve and J. Pairault, Eur. J. Pharmacol., 1996, 297, 107-119.
131 C. W. Liew, J. Boucher, J. K. Cheong, C. Vernochet, H. J. Koh, C. Mallol, K. Townsend, D. Langin, D. Kawamori, J. Hu, Y. H. Tseng, M. K. Hellerstein, S. R. Farmer, L. Goodyear, A. Doria, M. Bluher, S. I. Hsu and R. N. Kulkarni, Nat. Med., 2013, 19, 217-226. 